\title{
THE COMPETENCE OF NATIONS AND INTERNATIONAL TAX LAW
}

\begin{abstract}
ERIC T. LAITY*
"How is the cooperation of these vast numbers of people in countries all over the world, which is necessary for even a modest standard of living, to be brought about?",
\end{abstract}

\section{INTRODUCTION}

This article proposes a conceptual foundation for the field of international tax law. The Article refers to this foundation as the institutional competence of nations in global economic development. A nation's institutional competence may be defined as its discretion to make decisions in pursuit of our collective goal of global economic development, discretion that is subject to a number of standards and limitations.

The Article analyzes the institutional competence of nations in global economic development from the perspective of institutional economics, simple game theory, and the literature on social norms. The Article expresses the institutional competence of nations through standards and limitations that reduce the abuse of sovereign discretion and address international collective action problems in the pursuit of global economic development. These standards and limitations allocate prescriptive jurisdiction among nations over the global income tax base.

The foundation proposed by the Article would coordinate international taxation with the international regulation of trade. The Article also addresses the proper place of capital export neutrality in the hierarchy of values for economic development, the choice

* B.A., J.D. Harvard University. Professor of Law, Oklahoma City University School of Law. I can be reached at elaity@okcu.edu. This Article is copyright 2009 by Eric T. Laity. The research for this Article was made possible in part by a grant from the Kerr Foundation. I received helpful comments from Julie Roin, Gary J. Miller, Reuven S. Avi-Yonah, and J. Clifton Fleming. The remaining errors are mine.

1. Ronald H. Coase, The Wealth of Nations, 15 ECON. INQUIRY 309, 313 (July 1977) (stating the question that Adam Smith posed for himself). 
between territorial and worldwide tax systems, the evaluation of tax havens and appropriate responses, the use of anti-deferral regimes, and the possible need for a multilateral tax treaty.

On this institutional foundation, the role of the state is both essential and subordinate: sovereignty becomes an instrumental value and national law-making is seen in terms of a conceptual subsidiarity, to use the European term, or a consequentialist federalism in the realm of global economic development. Moreover, non-state actors facilitate sovereign competition and the benefits that such a constraint on the abuse of sovereign discretion brings to the world's people.

The Article begins with an analogy. Consider the manager of a complex organization. In order to obtain the best results, the manager must delegate decision-making authority to others. Furthermore, the delegation of decision-making authority must be accompanied by a grant of autonomy to the subordinate decision-makers, if the manager hopes to receive the full benefit of delegating decision-making authority.

Unfortunately, subordinate decision-makers can abuse their discretion. Subordinates might depart from the organization's goal and pursue their own objectives, possibly exploiting individuals under their control along the way. Furthermore, subordinates might attempt to shift their costs onto the budgets of other decision-makers on the same plane of authority. To minimize the abuse of discretion, the manager must create standards and limitations within which subordinate decision-makers are to exercise their autonomy.

The delegation of decision-making authority to multiple subordinates also creates collective action problems for those subordinates. Hence, the manager of the complex organization must encourage the development of social norms that coordinate collective action within the organization.

We can summarize the task of the manager of a complex organization. The manager must set the organization's overall goal. The manager must delegate decision-making authority and autonomy to subordinates within the organization. And, finally, the manager must create a decisional environment for those subordinates. The decisional environment consists of standards and limitations to minimize the abuse of delegated discretion and of social norms to coordinate the subordinates' collective action.

We can draw an analogy from the complex organization to the community of nations. Of course, we have no actual manager for the 
community of nations. We must posit a hypothetical manager and, following the lead of constitutional theory, we might refer to the world's people as the original source of authority for the community of nations. Assume that the goal our hypothetical manager has set for the community of nations is to improve our well-being. Assume, too, that some level of global economic development is necessary to provide the material basis for our well-being.

The nations of the world become the subordinate decisionmakers to whom the world's people have delegated authority and autonomy. Nations are to use their authority and autonomy to pursue the goal of improving our well-being and, in particular, to pursue some measure of global economic development.

Under the analogy, we must create a decisional environment for the world's nations that would allow us to benefit from decentralized decision-making while reducing its drawbacks. The decisional environment would consist, in part, of standards and limitations that curb the abuse of sovereign discretion. The decisional environment must also include the international equivalent of social norms that alleviate collective action problems among nations. This decisional environment defines the institutional competence of nations, an institutional competence that aligns the decisions of nations with our objective. When we shape the international decisional environment, we engage in the institutional design of nations.

This article engages in the institutional design of nations by proposing a decisional environment that would align national decisions about taxation with the goal of global economic development. The Article's objective is to gain the benefits of decentralized decision-making for the world's economy, while reducing the drawbacks. The Article assumes that the ultimate goals of the world's people require a measure of global economic development for their realization, regardless of how those ultimate goals may be defined.

This article proceeds as follows. Part I sets out the basic idea of the institutional competence of nations in global economic development. Part II describes the importance of using multiple sovereign decision-makers for global economic development. Part III addresses the abuse of sovereign discretion. It develops standards for and limitations on national decision-making about economic development, especially those applicable to the design of the international provisions of national income tax codes. Part IV deals with international collective action problems in global economic 
development, particularly those in international taxation. International social norms, such as the proposed standards and limitations, are the chief means for the coordination of national decision-making in pursuit of global economic development. Secondary norms aimed at key interest groups would enforce the standards and limitations. The Conclusion gives a summary of the Article's implications for international tax law.

\section{THE INSTITUTIONAL COMPETENCE OF NATIONS IN GLOBAL ECONOMIC DEVELOPMENT}

There is value to global economic development in having multiple nations involved in the decision-making. We can recognize some of that value by identifying the benefits to be derived from the delegation of decision-making authority to others. We might view the matter as a delegation of decision-making authority over global economic development by the world's people to the nations of the world.

Nations use some of their decision-making authority to craft environments for the economic development of their people. Those environments include property rights, markets, the rule of law, enabling law for privately created organizations, a bankruptcy regime, decentralized decision-making, competition, regulatory regimes, public infrastructure, an educated and healthy workforce, the provision of public goods and services, and various burdens including taxation and fees. ${ }^{2}$ Nations shape their economic environments for at least two reasons: to influence the decision-making of enterprises in favor of economic development and to enhance their tax revenue.

A nation also uses its decision-making authority to determine the optimal size of its public sector, that is, the optimal size of the aggregate of all activity funded by either tax revenue or public debt. The size of a nation's public sector is intertwined with its economic

2. See Douglass C. North, Institutions, Institutional Change and Economic PERFORMANCE 81 (1990) (describing institutional characteristics that are crucial to effective organization). Oliver Williamson calls adaptation the central problem of economic organization. Oliver E. Williamson, The Mechanisms of Governance 327 (1996) [herinafter Williamson, MECHANisms]. A government must create the conditions under which transactions will be aligned with modes of organization in light of their adaptive needs and capacities. See id. For vibrant development, nations must also offer credible commitments against expropriation of investment and an independent judiciary to enforce hybrid modes of governance created by the private sector. $I d$. at 330-33. Both are required if a nation is to attract high-value intangibles. $I d$. at 332-33. 
development. ${ }^{3}$ The revenue needs of a public sector affect the rate at which its economy grows. The tax burden on an economy necessarily limits the rate of capital formation, an essential ingredient in economic development. In this sense, the size of a nation's public sector is part of its economic environment. If a nation's economy grows, however, the nation's increased tax receipts permit an increase in the activities of its public sector. In this sense, a nation's economic development is subordinate to the long-term goals of its public sector.

A nation has a third decision to make from time to time concerning economic development. A nation must determine the distribution of the transition costs to higher standards of living. Although economic development raises standards of living for a population, the distribution of the benefit can be uneven; some members of the population may actually be worse off after the change to a higher overall standard of living. The nation must determine the distribution of such a detriment within that population.

There are two hazards in the delegation of decision-making. The first hazard is the decision-maker's abuse of its discretion in making decisions. We must limit a decision-maker's exercise of discretion if we are to reach the goal for which we have delegated decision-making authority.

The abuse of discretion can take several forms. A decision-maker can pursue goals other than the one for which it has been delegated decision-making authority. This form of abuse generates agency costs for the superior decision-maker. ${ }^{4}$ A decision-maker can also use its discretion to exploit subordinate actors. Such exploitation gives rise to a redistribution of wealth to actors who have captured the decision-making process. ${ }^{5}$ Thirdly, a decision-maker can take advantage of incomplete bargaining with other decision-makers on the same plane of authority, encumbering those decision-makers with externalities. ${ }^{6}$ Such opportunism can reduce the aggregate welfare of the people for whom the decision-makers are responsible.

3. Douglass North characterizes the size of a nation's public sector as one of the three most important keys to economic performance in the modern world. The other two keys are property rights and government regulation. NORTH, supra note 2, at 112 .

4. See, e.g., Michael C. Jensen \& William H. Meckling, Theory of the Firm: Managerial Behavior, Agency Costs and Ownership Structure, 3 J. FIN. ECON. 305, 308-10 (1976).

5. See, e.g., Mancur Olson, The Logic of Collective ACtion 29 (Harvard Univ. Press 1971).

6. See, e.g., GARY J. Miller, MANAGERIAl Dilemmas 36-57, 77-101 (1992). 
We can limit the abuse of sovereign discretion by specifying standards for and limitations on the economic environments created by sovereign decision-makers. Examples of those standards and limitations might include democratic accountability for the sovereign decision-maker and a code of human rights. Competition among sovereigns in the design of their economic environments serves as another limitation on their exploitation of subordinate actors. One of the benefits of having multiple decision-makers on the same plane of authority is the competition that is then possible.

The second hazard in the delegation of decision-making is the creation of collective action problems. This hazard is distinctive to the delegation of discretion to multiple decision-makers on the same plane of authority. There may be desirable global states of affairs that nations cannot reach through their individual efforts due to their inability to coordinate their decision-making.

We can address collective action problems through the standards and limitations we set on sovereign decision-making for economic development. An example of those standards and limitations is a ban on export subsidies. Thus, the standards and limitations on the design of a nation's economic environment address both abuses of sovereign discretion and collective action problems. To the extent that they address externalities and collective action problems, the standards and limitations serve as a set of property rights for sovereign decisionmakers.

Without a central authority to enact into law the standards and limitations we devise for national decision-making about economic development, those standards and limitations can only be the international equivalent of social norms. Furthermore, without a central authority, the standards and limitations can only be enforced through social norms of punishment. A sovereign failing to respect the standards and limitations on economic decision-making would subject itself to different treatment by other sovereigns. The international norms of punishment would specify the measured retaliation permitted in such an event.

Thus, the standards and limitations on a sovereign's decisionmaking about economic development would be of two kinds: a primary set of standards and limitations applicable to the nation's relations with other nations that observe those norms, and a secondary set applicable to the nation's relations with violators. A

7. International norms of punishment in the tax area are discussed infra Pt. IV.B. 
nation's tax code would have two sets of international provisions: one set applicable to nations in compliance with the primary norms and another set applicable to others.

We engage in institutional design when we formulate the standards and limitations governing national decision-making about global economic development. ${ }^{8}$ When applied to the international provisions of national income tax codes, the standards and limitations allocate among nations decision-making authority over the global income tax base. More generally, the standards and limitations allocate among nations the decision-making authority over global economic development. The standards and limitations define the institutional competence of nations in global economic development.

\section{THE VALUE OF MULTIPLE SOVEREIGNS}

We are engaged in the enterprise of global economic development for the benefit of the world's people. If we were starting from scratch, we would have to devise an environment that would foster economic development, taking into account the optimal size of the public sector and a fair distribution of transition costs. We would design that environment to influence the decision-making of individuals and companies in favor of global economic development. Our task would be easier and the result enhanced if we were to delegate the matter to multiple independent decision-makers. Each decision-maker would be responsible for creating a part of the global economic environment. We might divide the responsibilities by territory and make each decision-maker responsible for the people living there.

Of course, we are not starting from scratch. There are multiple nations in the world, and each is already engaged in crafting an environment for the economic development of its people. Yet, it is easy to overlook the value of multiple decision-makers in global economic development and push for the unilateral projection of a single nation's economic environment throughout the world.

We can see the value of multiple decision-makers in global economic development if we compare the arrangement to a complex organization with a central decision-maker. The delegation of decision-making authority by the central decision-maker improves

8. See also Herbert A. Simon, Administrative BeHAVIOR 1-17 (4th ed. 1997) (designing organizations to align the decision-making of individuals with the goals of the organization). 
the organization's performance.' The improvement is greater if the subordinate decision-makers have true autonomy; those subordinate decision-makers must reap the benefits of their decisions and bear the attendant burdens. ${ }^{10}$ Externalities between subordinate decisionmakers should be minimized: a decision-maker ought not to export its costs to another decision-maker, nor to seize the benefits accruing to another decision-maker. In the analogy to delegation within a complex organization, sovereignty becomes an instrumental concept based on the benefits to a complex organization of a grant of autonomy to subordinate decision-makers.

The delegation of decision-making authority to autonomous actors improves the performance of a complex organization in several ways. First, delegation releases, for the benefit of the organization, information and action otherwise withheld from the central decisionmaker. There are times when the incentives to withhold private information are such that the holders of the information must be given the authority to make the decisions for which such information is required if the organization is to benefit from that information. ${ }^{11}$ Even if the information is obtainable by the central decision-maker, it may be cheaper to delegate the decision-making to a person who already holds the information. Moreover, subordinates may be unwilling to implement central decisions if they have not participated in the decisions. Furthermore, the role of ignored or spurned interest groups in blocking local action or the revelation of local information should not be overlooked. ${ }^{12}$

In the case of global economic development, European Union economic policy gains the benefit of local information and action through the requirement that Union directives be implemented

9. See Miller, supra note 6, at 77-82. We may draw a parallel to the decentralization theorem of public economics. Under the theorem, the devolution of authority from a central government to local governments may increase the likelihood of innovation in public goods and of satisfying residents' preferences for public goods. See also William W. Bratton \& Joseph A. McCahery, The New Economics of Jurisdictional Competition: Devolutionary Federalism in a Second-Best World, 86 GEO. L.J. 201, 215-16, 261-62 (1997).

10. See MiLlER, supra note 6, at 216-21.

11. See id. at 139 ("the strategic misrepresentation of hidden information is itself the most profound obstacle to effective hierarchical performance").

12. See Miller, supra note 6, at 106-13 (describing peer pressure within interdependent work groups to mask the potential productivity of the group); see also DANIEL A. FARBER \& PHILIP P. FRICKEY, LAW AND PUBLIC CHOICE 19 (1991) (discussing the effectiveness of interest groups in blocking proposed legislation) (citing K. SCHLOZMAN \& J. TIERNEY, ORGANIZED INTERESTS AND AMERICAN DEMOCRACY 317 (1986)). 
through national legislation. ${ }^{13}$ National legislation can take local conditions, institutions, and practices into account. More generally, the construction of the global economic environment can benefit from local information and action if the construction is delegated to sovereign decision-makers.

A second benefit of delegation within a complex organization is the promotion of a variety of approaches to the organization's overall goal. This variety is due in part to the release of hidden information and action. The variety is also due to the Bendor effect: the delegation of authority to multiple independent subordinates improves the likelihood of generating new approaches to the organization's ultimate goal. ${ }^{14}$

In the case of global economic development, delegation would promote a variety of approaches to the creation of an economic environment conducive to development. Such variety is valuable to us because it enables us to use the comparative method to evaluate the efficacy of different economic environments, and, through that method, partly to overcome our inevitable lack of information about endowments, our inability to use controlled experiments in the public sphere, and the inevitable incompleteness of decision-making. ${ }^{15}$

In a world of perfect information, we would know the distribution of endowments within a society that would produce the highest standard of living for that society, given each individual member's preferences. In such a world, we would also know the existing distribution of endowments and thus the changes needed to achieve the optimal distribution. But, we cannot know the information necessary to determine or reach the optimal distribution of endowments for a society. ${ }^{16}$ The members of society have an incentive not to disclose the necessary information to us, which

13. For the requirement of national implementation of directives, see Treaty Establishing the European Community art. 249, Nov. 10, 1997, 1997 O.J. (C 340) 3.

14. See Miller, supra note 6, at 79-80 (citing JonATHAN BENDOR, PARALLEL Systems: REDUNDANCY IN GOVERNMENT 47 (1985)).

15. The comparative method is championed by transaction cost economics, among other schools. Transaction cost economics assesses "the comparative efficacy of alternative governance structures for harmonizing ex-post contractual relations." WILLIAMSON, MECHANISMS, supra note 2, at 177; see id. at 93-119. The comparative method mitigates the difficulty of measuring transaction costs. Oliver E. WILliamson, THE ECONOMIC InSTITUTIONS OF CAPITALISM 21-22 (The Free Press 1985) [hereinafter WiLLIAMSON, INSTITUTIONS]. The choice of institutions for a nation's economic environment involves tradeoffs, even among efficiency attributes. We need a variety of institutional mixes for study. See WILLIAMSON, MECHANISMS supra note 2, at 93-119.

16. See AMARTyA SEN, ON EthiCs AND ECONOMICS 36 (1987). 
includes information about their existing endowments. Such information remains essentially private.

We cannot run controlled experiments to determine the optimal distribution of endowments. It's not politically feasible to redistribute endowments, even on a temporary basis. ${ }^{17}$ A legislature with fully informed interest groups could not pursue the redistribution of endowments needed to reach the optimal distribution. Any inducement a person was paid to agree to the change would have to be counted toward that person's ideal starting position. Hence, we would have to lie about the ideal initial distribution of endowments. Nor could we verify the level of redistributed endowments, because we cannot determine the pre-existing distribution of endowments. Without determining the pre-existing distribution of endowments, we could not establish a control group, either.

A variety of approaches to the creation of an economic environment ameliorates the inevitable incompleteness of decisionmaking. Decision-makers make incomplete decisions, but the decisions are incomplete in different ways: decision-making is bounded by circumstances specific to the decision-maker. ${ }^{18}$ The alternatives we consider will be limited to those that we can imagine and further limited, by constraints on our time and resources, to those alternatives that intuitively seem most useful to analyze. ${ }^{19}$ The consequences we determine for those alternatives will be limited to those we can imagine and further limited by our expectations about what the actions of others will be. ${ }^{20}$ Because the time and information available for making a decision are limited, we must assume the truth or falsehood of some of the imagined consequences of an alternative. Our choice among sets of consequences will be limited partly by the sunk costs of our previous decisions. ${ }^{21}$ Our choice is more difficult if values are specific to concrete situations and therefore difficult to anticipate. ${ }^{22}$ Because decision-making time and attention are scarce resources, we devise habits, rules, and routines to conserve those resources. $^{23}$ Those habits in turn limit the alternatives and consequences we consider. A decision-maker faced with the demands

\footnotetext{
17. See id. at 37.

18. See SIMON, supra note 8 , at $45-47$.

19. See id. at $94,96-97,109$.

20. See id. at 78, 80-82, 93.

21. See id. at 77-78.

22. See id. at 93, 95-96.

23. See id. at 89.
} 
of rational choice may be tempted to identify with a group or role to reduce those demands. ${ }^{24}$

A third benefit of delegation within complex organizations is the competition it makes possible among decision-makers. The central decision-maker for the organization sets the terms of competition to encourage decision-makers to adopt the better approaches devised within the group or to formulate a more promising approach. ${ }^{25}$ In the case of global economic development, we would like sovereign decision-makers to adopt the better approaches to fostering economic development. Competition among nations is an aid to the diffusion of best practices. There is no central decision-maker setting the terms of competition, however. In order for sovereign competition to function, constituents must have the power to choose among national economic environments and the power to change incumbent officials. ${ }^{26}$

A fourth benefit of delegation within a complex organization is the improved decision-making it produces for the organization as a whole when unified action is needed. The Condorcet jury theory suggests that the alternative chosen by a group of autonomous decision-makers among the alternatives available will be better than the selection made by a single central decision-maker. ${ }^{27}$ In the case of global economic development, global decision-making is needed to select standards for and limitations on the creation of economic environments. The use of multiple sovereign decision-makers to make the selection should improve the chances that the best standards and limitations are selected.

\section{STANDARDS FOR AND LIMITATIONS ON SOVEREIGN DECISION-MAKING}

By reminding ourselves of the benefits of delegating decisionmaking authority within a complex organization, we recognized the benefits of having multiple sovereign decision-makers for global

24. See id. at 280-88.

25. See Alfred D. Chandler, The Visible HAnd: The Managerial Revolution in AMERICAN BUSINESS 457 (1977) (describing the rise and structure of the multidivisional firm, with central management evaluating the performance of the firm's divisions and allocating capital among the divisions). A multi-divisional company adds to the holding company structure the capabilities of strategic planning and resource allocation and the apparatus necessary for monitoring and control. See WiLLIAMSON, InSTITUTIONS, supra note 15, at 281.

26. These two powers of constituents permit the Tiebout and Salmon mechanisms to induce competition among governments. See Albert Breton, CoMPETITIVE Governments: An ECONOMIC THEORY OF POLITICS AND PUBLIC FinANCE 229-35 (1996).

27. See MILLER, supra note 6, at 80-82. 
economic development. If we remind ourselves of the drawbacks of delegating authority within a complex organization, we can recognize the hazards inherent in having multiple sovereign decision-makers.

Subordinate decision-makers within a complex organization may abuse their discretion and depart from the organization's goals. The departures impose agency costs on the organization and may exploit individuals or impose externalities on other decision-makers on the same plane of authority. To curb those departures, the organization must align the self-interest of its subordinate decision-makers with its goals. The organization's central decision-maker must design standards for and limitations on the subordinate decision-makers' exercise of discretion.

So, too, sovereign decision-makers may depart from our goal of global economic development as they craft their environments for economic development. If we are to avoid such departures, we must develop standards for and limitations on the exercise of sovereign discretion. The task of the standards and limitations is to align national self-interest, or more precisely, the self-interest of national decision-makers and the members of interest groups participating in domestic political and legislative processes, with our goal. Thus, sovereign decision-making is to foster national economic development that is consistent with global economic development. Our objective may also define the limits of private choice among the national economic environments. ${ }^{28}$

We can restate our enterprise in more general terms. Once we acknowledge the benefit of delegating decision-making authority in global economic development to multiple decision-makers, we must restrict the range of preferences that sovereign decision-makers may entertain in making their decisions if our overall goal of global economic development is to be served. A restricted range of national preferences is required if we are to retain at least the benefits of Pareto optimality in global economic development and transitivity in our global choices. ${ }^{29}$

28. For a discussion of anti-abuse rules, see infra Pt. IV.A.1. For a discussion of possible limits on private choice among national regulatory regimes, see Joel P. Trachtman, Economic Analysis of Prescriptive Jurisdiction, 42 VA. J. INT'L L. 1, 25-27 (2001). Trachtman would limit private choice among mandatory provisions of national regulatory law in order to retain such law's protection of third parties. Id. at 5-6.

29. See MiLler, supra note 6, at 86-101 (discussing the Sen Paradox, a corollary to Arrow's Theorem). 


\section{A. The Abuse of Sovereign Discretion}

The abuse of sovereign discretion has several causes. The selfinterest of a nation's decision-makers may lead to the abuse of sovereign discretion. The activity many elected officials find personally satisfying is meeting with and serving constituents. The self-interest of those officials is furthered by re-election to office and a generous budget with which to meet constituents' needs. Economic development serves the self-interest of a nation's public decisionmakers if it minimizes unemployment during elections and increases the nation's tax revenues. A government might envision the creation of an environment for vibrant economic development as an investment it makes with the expectation of an increase in its future revenues and the employment of its people. ${ }^{30} \mathrm{~A}$ vibrant economic environment enhances the value of the government's net profits interest in its private enterprises and its net revenue interest in its people's consumption. The immediate needs of incumbent public decision-makers, however, can lead them to subvert the long-term benefits from economic development by seizing additional revenue or creating unsustainable employment in the present term.

Organized groups that participate in the domestic political and law-making processes contribute to the abuse of sovereign discretion. In general, economic interest groups would like to reduce the burden of competition. They strive to reduce that burden through the segmentation of markets, the erection of barriers to entry, and public subsidies of their costs. When nations introduce protectionist measures to segment global markets into national ones or subsidize their enterprises' participation in global markets, they depart from the goal of global economic development. The departure imposes agency costs on the world community, which are borne by voters everywhere. By increasing the costs to consumers within the enacting nation's jurisdiction, the departure exploits those subordinate actors through a redistribution of wealth. By imposing externalities on other nations' economic environments, the departure is opportunistic. Such externalities interfere with the effectiveness of nations' decisionmaking about their economic environments.

30. William Barker sees the basis for a nation's income tax to be the value the nation has added "to the world." He sees this basis as neither the benefit conferred by a nation upon the taxpayer nor the taxpayer's ability to pay. William B. Barker, Optimal International Taxation and Tax Competition: Overcoming the Contradictions, 22 Nw. J. INT'L L. \& BUS. 161, 162, 186-88 (2002). 
A nation's decision-makers and its organized groups can combine to redistribute wealth through the design of institutions for its national economic environment. The choice and design of institution depends on the transaction costs borne by three groups of actors: sponsoring legislators, interested constituents, and the holders of residual interests. ${ }^{31}$ The members of the sponsoring legislative coalition incur decision-making costs as well as the commitment costs of making the redistribution durable through subsequent legislative sessions. Interested constituents not only bear the usual agency costs of pursuing their goals through representatives and the costs of unintended consequences, but they also must evaluate the cost of participating in the subsequent interpretation and enforcement of their legislated benefits. The holders of the residual interests in government intervention include taxpayers, competitors, holders of public debt, and consumers. The costs to consumers of organizing to champion the benefits from economic development as a counterweight to redistribution are thought to be sufficiently high to prevent consumers from having an effective voice in government. ${ }^{32}$ Thus, the standards and limitations for sovereign discretion must champion the interests of consumers.

The transaction costs of those three groups shape the preferences of the individuals composing the legislative coalition. The coalition's choice of institution depends in part on the relative homogeneity of the legislators' preferences. ${ }^{33}$ Complete decisions can be made by a legislature when the range of legislator preferences on an issue is limited. When a legislature does not have sufficiently homogeneous preferences on an issue to enact comprehensive legislation, but the

31. See Murray J. Horn, The Political Economy of Public Administration: Institutional Choice In the Public SECTOR 13-22 (1995). Some of the transaction costs considered by enacting coalitions and their supporters in their choice of institution to deliver durable benefits include the ease of subsequent intervention in the affairs of the institution, the relative lack of transparency afforded by the institution for pursuing redistributive goals, the means of funding redistributive goals (for example, through a statutory monopoly or through cross-subsidies by regulation), the political strength of the residual claimants (who under the circumstances can include competitors, consumers, taxpayers, or government creditors), the commitment costs of special privileges for the institution, the degree to which management must be decentralized (which raises agency costs), and the ability of beneficiaries to sustain an ongoing interest in the management of the institution.

32. For this reason, free trade legislation must be championed by industries that benefit from the elimination of trade barriers, despite the significant benefits to consumers from such legislation. Without those industrial proxies for consumers, free trade legislation would be blocked by those industries losing economic rent through the elimination of trade barriers.

33. See HORN, supra note 31 , at 15. 
range of preferences is still fairly well contained, the legislature will enact legislation that delegates further decision-making to a hierarchy, such as an administrative agency, a for-profit enterprise, or a non-profit enterprise. Tax expenditures can subsidize for-profit organizations or use them as administrators for subsidies to their employees. A hierarchy can make more detailed decisions than a legislature can because of the centralized authority of the executive and through a further restriction of the set of preferences held by individuals within the hierarchy through a combination of incentive systems, personnel selection, and the creation and maintenance of social norms. ${ }^{34}$

Where the range of preferences in the legislature is broad enough to prevent delegation to a hierarchy, but sufficiently limited to permit the legislature to enact vague legislation, the legislature in effect delegates more detailed decision-making to the courts. ${ }^{35}$ When the range of legislators' preferences is too broad to permit any legislation, the decision-making is left to the markets and their existing hierarchies. The existing hierarchies grapple with collective action problems arising in circumstances of interdependent work or limited information, and the markets are able to make decisions under other circumstances. ${ }^{36}$

A sovereign decision-maker must be concerned with the abuse by subordinate actors, including private enterprises, of any discretion it confers upon them. We will have occasion later in this Article to take up anti-abuse rules.

\section{B. Standards to Reduce the Abuse of Sovereign Discretion}

As we design the institutional competence of nations for global economic development, our challenge is to preserve the benefits of having multiple, autonomous decision-makers while curbing their abuses of discretion. We may curb the abuse of sovereign discretion through the creation of standards for and limitations on the exercise of discretion in shaping an environment for global economic

34. See MiLler, supra note 6, at 58-74, 86-101, 179-81 (comparing decision-making by voting and by hierarchy, and the restriction of preferences within a hierarchy).

35. See HorN, supra note 31, at 15 (describing the broad range of preferences within a legislature creating high legislative transaction costs, leading to vague legislation). The vagueness of such legislation gives courts discretion in its interpretation and application.

36. See Miller, supra note 6, at 31-34; Armen Alchian \& Harold Demsetz, Production, Information Costs, and Economic Organization, 62 AM. ECON. REV. 777 (1972). 
development. ${ }^{37}$ Standards structure how a sovereign exercises its discretion within its sphere of autonomy, while limitations define the boundaries between sovereigns' spheres of autonomy. Standards address the exploitation of individuals subject to the sovereign's authority and the agency costs that arise from exploitation. In contrast, limitations address opportunism in international relations and the agency costs that arise from opportunism.

By curbing abuses of sovereign discretion, the standards and limitations help to define the institutional competence of nations in the realm of global economic development. Such institutional competence can then serve as the common foundation for the norms of international trade and taxation. The norms of international taxation must preserve the benefits for global economic development of having multiple autonomous decision-makers, while observing the standards and limitations on the exercise of sovereign discretion.

Many of the standards and limitations that define the institutional competence of nations in global economic development already exist and are recognized in other contexts. Other standards and limitations have yet to be adopted.

I take up standards first. Some of the standards for the exercise of sovereign discretion govern a nation's political and legal processes, while other standards affect the structure of a nation's markets, the design of national legislation, and competition among sovereigns.

1. Standards for Political and Legal Processes

Standards that govern political and legal processes reduce the exploitation of individuals by making it more difficult for national decision-makers and organized groups to redistribute wealth to themselves through those processes. Such standards include democratic accountability, a code of individual rights, an independent judiciary, and the rule of law. Federal systems of government might be necessary for nations with large populations. Federal systems prevent central governments from delegating too little decisionmaking authority to political subdivisions or giving those subdivisions too little autonomy in their decision-making for effective economic

37. These standards and limitations are the international equivalent of social norms and are created through treaties and customary international law. See supra Pt. I and infra Pt. IV.

38. This Article suggests three norms of international taxation. See infra Pt. III.C.2. 
development. Federal systems may also give credibility to a government's commitment not to seize the property of its people. ${ }^{39}$

Transparency in and auditing of government expenditures also are useful standards. For example, the World Bank required the Republic of Chad, as a condition to financing the construction of an oil pipeline, to direct the payment of all pipeline revenues into an account controlled by a third person. Funds in the account can only be used for expenditures that benefit the people of Chad. ${ }^{40}$ Such an arrangement inhibits the clandestine transfer of pipeline revenues to an elite. The arrangement also helps pipeline customers avoid charges of complicity in any future governmental malfeasance.

2. Standards for the Structure of Markets

Standards for competition among enterprises enhance consumer welfare, even in opposition to groups that seek economic rents through industrial structure and restraints on trade. Standards for competition remove impediments that otherwise would segment a market and shelter enterprises from the pressures of competition. A sovereign's failure to use its discretion for the benefit of its consumers exploits those individuals in the sense that enterprises continue to benefit from the existing segmented structure of the markets. To the extent that the sovereign's failure has decreased the rate of its people's economic development from what is feasible, the failure has generated agency costs.

\section{Standards of Neutrality for Legislation}

Standards are needed to counteract the legislative exploits of organized groups. The norms of the General Agreement on Tariffs and Trade (GATT) impose standards of neutrality on national lawmaking. ${ }^{41}$ These standards assist in the promotion of competition by creating even larger markets. The standards of neutrality include nondiscrimination - national treatment and most favored nation treatment - and transparency. ${ }^{42}$ These standards remove impediments

39. See Barry R. Weingast, Constitutions as Governance Structures: The Political Foundations of Secure Markets, 149 J. INST'L \& THEORETICAL ECON. 286, 287-90 (1993).

40. See Oil in Chad, ECONOMIST, Sept. 14, 2002, at 49.

41. See PAul B. Stephan ET Al., InTERnAtional Business AND ECONOMICS: LAW AND POLICY 875 (3d ed. 2004) ("In essence, the GATT advances liberal norms (unhampered [international] movement of goods, capital and people) ....").

42. See General Agreement on Tariffs and Trade arts. I, III, XI, Oct. 30, 1947, 61 Stat. A11, 55 U.N.T.S. 194 [hereinafter GATT] (containing the most favored nation treatment for GATT members, national treatment of foreign-produced products in matters of taxation and 
at the international level that otherwise would segment national markets by a product's national origin or would segment international markets along national or regional lines. Standards of neutrality impede rent-seeking by sub-national groups, which market segmentation would facilitate.

Standards that counter the legislative exploits of organized groups also affect the design of national income tax codes. Organized groups attempt to influence the design of tax codes to skew the burden of public expenditure away from themselves. The intent of organized groups can be countered by standards of neutrality similar to those embodied by the norms of GATT.

A tax code ought to be a neutral factor in business and investment decisions made within a nation's own economic environment. An income tax code should not change the relative prices of goods and services in the private sector. ${ }^{43}$ To achieve a neutral effect on relative prices, the distribution of the burden of public expenditure should be neutral among similarly situated taxpayers. Neutrality in the taxation of similarly situated taxpayers, sometimes known as horizontal equity, also preserves the benefits of the delegation by sovereigns of decision-making authority to multiple enterprises within their economic environments. In those circumstances, equity is a means to institutional efficiency. Furthermore, a tax code should not discriminate between a domestic enterprise of a foreign entity and a domestic enterprise of a domestic entity. A tax code should be neutral as between the two. Moreover, a tax code should not discriminate against a resident taxpayer's foreign production. Lastly, the norm of transparency requires that the tax subsidies in a tax code be identified and included in the national budgeting process.

Tax norms of neutrality keep a tax system from contributing to the segmentation of a nation's markets. If competitors as similarly situated taxpayers labor under different income tax rates and if the traditional assumption that the incidence of the corporate income tax falls entirely on shareholders is false, then the tax system has raised a

regulation, and transparency in measures restricting trade by converting all such measures into monetary charges, respectively). The norm of most favored nation treatment requires each GATT member to make available to all other members any trade benefit it makes available to any single member. Under the norm of national treatment, a member of GATT must treat foreign-produced products the same as it treats domestically produced products for purposes of taxation and regulation.

43. Barker, supra note 30 , at $188-89$. 
semi-permeable boundary between those competitors. ${ }^{44}$ If some of those competitors are foreign investors, the tax code has segmented markets along national lines.

\section{Sovereign Competition as a Standard}

There is another standard that has the potential to reduce the exploitation of individuals by organized groups through political and legislative processes. Competition among sovereigns in the design of national economic environments reduces the exploitation of individuals by organized groups. ${ }^{45}$ A nation's need to maintain living standards similar to those enjoyed in neighboring countries is a useful check on rent-seeking by economic groups. Furthermore, sovereign competition may lead to tax reform. ${ }^{46}$ A nation's need to broaden its tax base and reduce its tax rate acts as a counterweight to the inevitable pressure for tax subsidies and benefits residual groups who otherwise would bear the cost of tax subsidies through higher tax rates. ${ }^{47}$ Tax competition may also lessen the discrimination against foreign investors, who otherwise present a tempting source of additional revenue external to a nation's electorate..$^{48}$ In this sense, competition supports the standard of nondiscrimination for the legislative process. Moreover, sovereign competition helps to generate and evaluate different national environments for economic development.

The movement of individuals and enterprises among nations promotes sovereign competition. The free movement of capital among national economic environments, then, must be a standard for the exercise of sovereign discretion. ${ }^{49}$ A national tax code generally

44. For a discussion of the incidence of a corporate income tax, see infra Pt. III.D.2.

45. See also Albert Breton et al., Decentralization and Subsidiarity: Toward a Theoretical Reconciliation, 19 U. PA. J. INT’L ECON. L. 21, 43 (1998) (“[C]ompetition facilitates the control and regulation of the exercise of political power.").

46. See also ORg. FOR ECONOMIC CO-OPERATION AND DEV., HARMFul TAX COMPETITION: AN EMERGING IsSUE 13-14 (1998) [hereinafter OECD]. "Globalization has also been one of the driving forces behind tax reforms, which have focused on base broadening and rate reductions, thereby minimizing tax induced distortions." Id. at 13.

47. Note, however, that such tax reform may be accompanied by increased government borrowing to fund direct subsidies that replace the tax subsidies.

48. See Julie Roin, Competition and Evasion: Another Perspective on International Tax Competition, 89 GEO. L.J. 543, 580-85 (2001) (funding a state's redistributive goals through discriminatory taxation of foreign investors).

49. Removing impediments to foreign portfolio investment can be beneficial to a nation's capital markets. See PAUL R. KRUGMAN \& MAURICE OBSTFELD, INTERNATIONAL ECONOMICS: THEORY AND POLICY 652-53 (4th ed. 1997); Barry Eichengreen et al., Capital 
should not impede the movement of investment among nations. In particular, a nation's tax code should not discriminate against the foreign investment of its residents, if sovereign competition is to serve its purpose. ${ }^{50}$ A sovereign ought not to tie its investors to its own capital markets. ${ }^{51}$

International capital markets also encourage sovereign competition. The pricing of sovereign debt transmits useful information about the relative success of national economic environments in fostering economic development.

\section{Limitations on the Abuse of Sovereign Discretion}

The other kind of measure that reduces the abuse of sovereign discretion in the shaping of an economic environment are limitations. Limitations reduce opportunism in international economic relations by making the cross-border transfer of costs and benefits more difficult for national decision-makers and organized groups. Limitations serve a function among nations similar to that of property rights.

Within their spheres of autonomy and subject to the standards for exercising sovereign discretion, nations would experiment in the design of their economic environments. A comparative evaluation of those economic environments will help us identify those promoting

Account Liberalization: Theoretical and Practical Aspects 12 (Int'l Monetary Fund Occasional Paper 172, 1998). The greater supply of portfolio capital should lower the cost of capital in that nation. Suppliers of portfolio capital are subject to behavioral peculiarities documented by behavioral economists; those peculiarities lead to crises in capital markets, which need to be buffered. See Jagdish Bhagwati, The Capital Myth: The Difference Between Trade in Widgets and Dollars, 77 FOREIGN AFF., May-June 1998, at 7; but see Economics Focus: Capital Controversies, ECONOMIST, May 21, 1998, at 72 (partly taking issue with Bhagwati's article). Removing impediments to foreign direct investment may also be beneficial. Foreign direct investment does not contribute supply to a nation's capital markets, but does provide additional production for the nation's other markets.

50. At present, neither international trade law nor international tax law prohibits a residence nation's discrimination against foreign production by its residents. See Alvin C. Warren, Jr., Income Tax Discrimination Against International Commerce, 54 TAX. L. REV. 131, 158 (2001). An example of such discrimination is accelerated depreciation available only for equipment used domestically. $I d$. Other examples include the limitation of shareholder imputation credits to dividends attributable to domestic source income. Id. at 154 .

51. The Netherlands violated the Treaty of Rome's provision requiring free movement of capital when the Dutch income tax system gave imputation credits to shareholders only for dividends received from Dutch companies and not for dividends received from other EU companies. Case C-35/98, Staatssecretaris van Financiën v. B.G.M. Verkooijen, 2000 E.C.R. I4071. Under the Dutch imputation system, Dutch portfolio investors had an incentive to participate only in Dutch equity markets. 
robust development. To preserve those experiments and the integrity of our comparative evaluation, we must avoid the imposition of externalities by one economic environment on another. Limitations are the measures channeling sovereign discretion that reduce the imposition of externalities between national spheres of autonomy.

Consider the drawbacks of sovereign competition. ${ }^{52}$ Competition among sovereigns can take the form of the imposition of costs by one sovereign on another's economic environment or the taking of benefits by one sovereign from another's economic environment. The imposition of externalities transfers wealth from one sovereign to another (possibly with a net loss of wealth), impairs the effectiveness of the burdened sovereign's economic environment, and distorts the economic decision-making of both sovereigns.

The cause of opportunistic competition among sovereigns lies with the national decision-makers and organized groups of the exploiting sovereign. In the case of a cost, the constituents of the burdened sovereign become an additional residual group to bear the cost of the exploiting sovereign's national legislation (a residual group to which the national decision-makers of the exploiting sovereign are not accountable, even in theory). In the case of a benefit, the nation's decision-makers seek additional revenue without burdening their own constituents and reducing the rate of capital formation within their

52. Reuven Avi-Yonah fears that technological change and tax competition among nations may reduce global tax revenue over time. The use of electronic commerce rather than permanent establishments to distribute goods and services will shift taxable income from consumption jurisdictions to production jurisdictions. Furthermore, competition among nations as production jurisdictions will encourage business entities to transfer their production to production tax havens. The shift of the global tax base in favor of production tax havens will reduce business income tax receipts in consumption jurisdictions. See Reuven S. Avi-Yonah, Globalization, Tax Competition, and the Fiscal Crisis of the Welfare State, 113 HARV. L. REV. 1573, 1586-97 (2000) [hereinafter Avi-Yonah, Globalization]; see also OECD, supra note 46, at 14 (tax competition reducing nations' ability to meet redistributive goals through tax revenue). I have several comments on Avi-Yonah's assertion. First, we should not lose sight of our overall goal: economic development that increases the well-being of the world's people. If such shifts improve the well-being of the world's people, we should welcome them. Tax revenue is not the highest good. Second, if such shifts are accompanied by greater global economic development, any shifts may well be accompanied by an increase in the global tax base, especially when we take into account personal income and aggregate payrolls. Third, tax jurisdictions aren't necessarily fungible. Their marginal costs and benefits will differ in offering compelling economic environments to foreign investment. Without fungibility, tax competition will be limited. See Roin, supra note 48, at 543, 554-62, 568-80. Fourth, transaction costs or "frictions" may stymie tax competition. See Bratton \& McCahery, supra note 9, at 231-39, 260 (identifying the frictions of externalities, costs of mobility, bundled public goods, asymmetric information, spillovers, and the possible lack of entrepreneurs in public goods). 
own economy. The burden of the revenue taken from another sovereign falls on that nation's constituents and economy.

In the case of a complex organization, the central decision-maker must limit opportunistic competition among the organization's subordinate decision-makers if the organization is to benefit fully from the grant of autonomy to those decision-makers. So, too, in the case of global economic development, we must limit opportunistic competition among nations if we are to benefit fully from the participation of multiple sovereigns in the shaping of the global economic environment.

Limitations on a sovereign's decision-making address opportunism by prohibiting subsidies and taxation that invade other sovereigns' spheres of autonomy over the global economic environment.

\section{Limitations on Subsidies.}

The norms of the General Agreement on Tariffs and Trade (GATT) address opportunistic sovereign competition executed through subsidies. GATT prohibits export subsidies, which ameliorate the general burden of a nation's economic environment for those engaged in international trade and increase the profit margin of exporters. ${ }^{53}$ Export subsidies can also be an attempt to keep a non-competitive feature of a nation's economic environment in place but to waive it for the benefit of exporters. Tax expenditures that subsidize exports are subject to the norms of GATT. ${ }^{54}$ GATT also permits measured retaliation against domestic subsidies of specific impact, which generally are elements of a national economic environment that benefit specific industries. ${ }^{55}$ Both kinds of subsidies

53. For the prohibition on export subsidies, see GATT, supra note 42, art. XVI; Agreement on Subsidies and Countervailing Measures art. 3.1(a), Apr. 15, 1994, Marrakesh Agreement Establishing the World Trade Organization, Annex 1A, 1 LEGAL INSTRUMENTS - RESULTS OF THE URUGUAY Round (1994) [hereinafter SCM Agreement]. At present, the ban on export subsidies only reaches trade in goods. Neither GATT nor the SCM Agreement reaches export subsidies for services or investment.

54. See SCM Agreement, supra note 53, art. 1, II 1.1(a)(1)(ii); Paul R. McDaniel, Trade and Taxation, 26 BROOK. J. INT'L L. 1621, 1637-39 (2001). An exemption system in itself does not constitute an illegal export subsidy under GATT, although its application to transactions that originate in the residence state is an export subsidy under GATT. McDaniel, supra, at 1628.

55. See SCM Agreement, supra note 53, art. 2, II 2.1. In addition to having specific impact, domestic subsidies must also be contingent upon either export performance or the use of domestic goods over imported goods. Id. art. 3, II 3.1 . 
skew competition among private enterprises in international markets.

The GATT approach generally encourages the modification of the nation's economic environment so the non-competitive element is eliminated for all actors and the beneficial element is either made available to all or to no one. ${ }^{57}$ In this sense, GATT requires sovereign competition to affect all of a sovereign's constituents when it indirectly affects the constituents of other sovereigns. GATT's norms dealing with subsidies thus indirectly act as standards reducing the exploitation of a sovereign's own constituents through non-uniform treatment. More generally, we should encourage competition among sovereigns on the basis of the uniform application of their economic environments and not on the basis of departures from selected elements of a national economic environment, if we are to avoid the exploitation of members of residual groups by organized groups.

2. Limitations on Taxation.

Limitations also promote global economic development by defining a nation's prescriptive jurisdiction over the global income tax base. The limitations define the opportunistic taking of revenue by one sovereign from another sovereign's economic environment. ${ }^{58}$ In

56. Paul McDaniel identifies three negative effects of export subsidies, including those distributed through tax subsidies: the skewing of sales away from third-country producers who have a comparative advantage over the subsidized producers, the missed opportunity by the subsidized producers to achieve new efficiencies, and possible retaliation by third countries through competing subsidies. See Paul R. McDaniel, Trade Agreements and Income Taxation: Interactions, Conflicts, and Resolutions, 57 TAX L. REV. 275, 295 (2004) [hereinafter, McDaniel, Trade Agreements]. Export subsidies may also increase the value of the subsidizing nation's currency, reducing the benefit of the subsidy without reducing its cost to the nation's taxpayers. See id. at 296.

57. The GATT approach is reflected in the panel report on U.S. foreign sales corporations: The United States is free to maintain a world wide tax system, a territorial tax system or any other system it sees fit. This is not the business of the WTO. What it is not free to do is to establish a regime of direct taxation, provide an exemption from direct taxes specifically related to exports, and then claim it is entitled to provide such an export subsidy because it is necessary to eliminate a disadvantage to exporters created by the US tax system itself. In our view, this is no different from imposing a corporate tax of, say, 75 per cent, and then arguing that a special tax rate of 25 per cent for exporters is necessary because the generally applicable corporate tax rates in other Members is only 25 percent.

Panel Report, United States - Tax Treatment for "Foreign Sales Corporations", II 7.122, WT/DS108/R (Oct. 8, 1999) (footnote omitted).

58. Daniel Shaviro calls such opportunism "tax exportation." Through tax exportation, a government places a burden on outsiders who neither consent to the burden nor share in the 
general, a national income tax code ought not to impose externalities on other nations if our economic decision-making is to be sound.

There are several kinds of externalities we must avoid. We must avoid externalities that impair the benefits of having multiple sovereigns involved in global economic development. Furthermore, we must avoid externalities that impair incentives for other nations to foster economic development, including capital formation. Moreover, we must avoid externalities that impair the competitiveness of other nations' markets.

Our overall goal of global economic development gives us three limitations on the design of national tax codes. First, a nation must have exclusive prescriptive jurisdiction over the income derived from business operations conducted within its territory. ${ }^{59}$ Second, a nation

benefit funded by the burden. Daniel Shaviro, An Economic and Political Look at Federalism in Taxation, 90 MiCH. L. REV. 895, 908 (1992).

59. To the extent that such things can be predicted, there apparently would not be a revenue loss if the United States moved to an exemption system for the taxation of business income. Tax revenue for the United States might actually increase. See Harry Grubert, Enacting Dividend Exemption and Tax Revenue, 54 NAT'L TAX J. 811, 816-17 (2001) (estimating a revenue increase of nine billion dollars annually, assuming that foreign-source royalty income continues to be subject to residence-based taxation [under an exemption system, foreign-source royalty income could no longer be sheltered by excess foreign tax credits]); see also Keith Engel, Tax Neutrality to the Left, International Competitiveness to the Right, Stuck in the Middle with Subpart F, 79 TEX. L. REV. 1525, 1568 (2001). This possible revenue enhancement affects the use of an exemption system to encourage investment in developing nations. Michael Graetz discusses the use of the international aspects of a nation's tax code to redistribute future income to developing nations through the encouragement of foreign investment. See Michael J. Graetz, Taxing International Income: Inadequate Principles, Outdated Concepts, and Unsatisfactory Policies, 54 TAX L. REV. 261, 300-01, 309 (2001). The shift to an exemption system apparently would eliminate one of the existing incentives for multinational business to invest in production facilities in low tax jurisdictions: the need to absorb taxes from high-tax jurisdictions through cross-crediting. For additional analysis of the needs of developing nations and the international provisions of national tax codes, see Karen B. Brown, Harmful Tax Competition: The OECD View, 32 GeO. WASH. J. INT'L L. \& ECON. 311 (1999). For the U.S. tax system, David Rosenbloom proposes to ignore the corporate form of foreign subsidiaries and to exempt from U.S.-residence-based taxation the business profits of branches and subsidiaries attributable to permanent establishments in nations that appear on a list of nations with well-developed tax systems. See H. David Rosenbloom, From the Bottom Up: Taxing the Income of Foreign Controlled Corporations, 26 BROOK. J. INT'L L. 1525, 1544-48 (2001). All other income of the foreign subsidiaries would be taxed currently by the United States with a deduction for foreign income taxes paid. $I d$. at 1548-50. The gain on appreciated property transferred to a permanent establishment would also be taxed currently. Id. at 1552-53. Rosenbloom's proposal would eliminate the foreign tax credit and Subpart F, but would not address the reincorporation of multinational enterprises in tax havens. Robert Peroni points out the temptation for the federal government to delist countries as a weapon of foreign relations. Robert J. Peroni, The Proper Approach for Taxing the Income of Foreign Controlled Corporations, 26 BROOK. J. INT'L L. 1579, 1590-91 (2001). 
must have exclusive prescriptive jurisdiction over portfolio income derived anywhere in the world from capital accumulated within its territory. ${ }^{60}$ Third, a nation's tax code must be transparent to the tax authorities of other nations when the code acts as a conduit for portfolio investment by residents of other nations.

These three limitations are based in part on the value to global economic development of the use of multiple sovereign decisionmakers in the shaping of the global economic environment. We have seen that the use of multiple autonomous decision-makers gives us, among other things, a variety of approaches in the design of national economic environments. ${ }^{61}$ That variety is essential because it enables us to use the comparative method to evaluate the relative efficacy of different economic environments, thus partly overcoming our inherent lack of information about endowments, our inability to use controlled experiments in the public sphere, and the inevitable incompleteness of decision-making. ${ }^{62}$ It is only through the comparison of different economic environments that we can determine the effect of different institutional arrangements on economic performance. The use of multiple sovereign decisionmakers also gives us the benefit of sovereign competition. ${ }^{63}$ Sovereign competition forces nations to be attentive to the cultivation of their economic environments.

Low-income nations that suffer from chronically poor economic performance usually have institutional arrangements that impede effective economic change. An international decisional environment that promotes global economic development should encourage government decision-makers in low-income nations to create better economies. We have already discussed the role in economic development of standards for government decision-making. The creation of a stronger economy also depends on government decisionmakers shaping an economic environment that presents proper incentives to public and private entrepreneurs to engage in productive activity.

60. William Barker reaches a similar conclusion, but partly on the basis of equity. See Barker, supra note 30, at 162, 195-97.

61. See supra Pt. II. Other benefits of the use of multiple sovereign decision-makers in global economic development include the release of information and action hidden from a central decision-maker, competition among decision-makers, and improved decision-making when unified global action is needed. Id.

62. See supra notes 13-23 and accompanying text.

63. See supra $\mathrm{Pt}$. II, at notes 24-25. 
In terms of public finance, we ask government decision-makers to be attentive to the design of their economic environments and to avoid confiscatory measures to address their immediate problems. Government decision-makers must see their economic environments as assets to be cultivated. Cultivation of such an asset might consist of building infrastructure, investing in human capital through health and education, or leaving retained earnings within the economy to become additional capital. Any of these measures would increase the value of the economic environment and, from the government's point of view, increase its revenue stream from the asset.

Low-income nations usually have primitive infrastructure, including their facilities for health and education. One route a lowincome nation might take is to set a low rate of tax to compensate for the necessary private investment in substitute infrastructure. If the selflessness of government decision-makers is in question, one might prefer the infrastructure to be built by private enterprises and as it is needed rather than by the government.

To preserve the value of multiple sovereign decision-makers, we must address the temptation of autonomous decision-makers not to bear the full market consequences of their decisions but to import benefits from and export burdens to other national economic environments. The three limitations on the design of national tax codes address this temptation by defining the boundaries among national spheres of autonomy in taxation. In doing so, the limitations lay down rules for sovereign competition in taxation.

Two decisions that a sovereign decision-maker must make, and for which we seek a variety of answers, are the size of a nation's public sector and the rate of capital formation within the nation's economic environment. The two decisions are interrelated. Thus, in designing its income tax code, a nation must determine the trade-off between private capital formation, on the one hand, and government consumption and investment, on the other. In effect, a nation must determine the size of its public sector both now and in the future. The higher the tax rate on business income, the lower the rate of capital formation by taxable enterprises can be. One factor a nation must take into account in a decision to lower the tax rate on business 
income is the likely future tax revenue that additional capital would generate. $^{64}$

This leads us to the first limitation. We must grant each nation exclusive prescriptive jurisdiction over the income from business operations conducted within its economic environment, if the nation is to control the trade-off between current consumption and capital formation. If other nations impose a tax burden on its business operations, the additional burden will reduce the possible rate of capital formation within its economic environment and the future return on its foregone consumption. The uncertainty of its future return would encourage a nation to abandon the global goal of capital formation and take what tax revenue it can for current consumption.

The second limitation is also related to capital formation and the size of a nation's public sector. We must assure a nation that it will retain prescriptive jurisdiction over the future returns on capital formed within its economic environment. Thus, a nation should have prescriptive jurisdiction over portfolio income arising from capital accumulated within its economic environment, regardless of where the capital is later invested. Moreover, such jurisdiction must be exclusive. If it is not, the nation cannot determine, or rely on, the compounding effect of capital formation within its economic environment. The uncertainty of its compounded future return encourages a nation to abandon the global goal of capital formation in favor of current consumption.

Business income is the residual made possible in part by a nation's economic environment. Portfolio income is the return on capital; capital is made possible by a government's decision to forego immediate taxation of all of the residual of a business operation. To preserve incentives to the government in its cultivation of its economic environment, we should leave the residual within the government's exclusive prescriptive jurisdiction and leave the portfolio income there as well. Thus, the different treatment of business income and portfolio income proposed here is the result of preserving the same incentive to governments to cultivate their economic environments.

The first limitation would also preserve the competitiveness of other nations' markets. To the extent that a corporate income tax is

64. For an illustration of the interplay between the size of a nation's public sector, its public debt, taxation, and its economic development, see What's Holding India Back?, ECONOMIST, Mar. 6, 2008, www.economist.com/opinion/displaystory.cfm?story_id=10808493. 
borne in part by customers, a supplementary income tax imposed by one nation on activities conducted within another nation can reduce competition within that other nation's markets. The supplementary income tax would affect the relative prices of otherwise competing goods.

The third limitation requires transparency in the administration of tax codes. Such transparency combats the use of one nation's laws by taxpayers of another nation to evade their own nation's valid taxes. Transparency in the administration of tax codes prevents the imposition of externalities by financial tax havens on consumption jurisdictions. Through their bank secrecy laws, financial tax havens encourage the evasion of home nation taxation to their profit. Transparency in the administration of tax codes requires that bank secrecy laws be subordinate to the needs of tax administration.

The secrecy of tax information has several undesirable effects. ${ }^{65}$ Such secrecy relieves the pressure from powerful individuals against the enactment of confiscatory tax regimes; such individuals can protect their income through non-transparent offshore investment rather than moving to forestall the confiscatory taxation in the first place. The effective exemption of such favored individuals from the full brunt of a nation's tax code opens the door to discriminatory taxation of those without access to offshore investments. Furthermore, the secrecy of tax information increases the opportunities of corrupt administrators and advisors to extract rents from the investors they serve. The secrecy of tax and banking information is sometimes justified on the grounds that it prevents the misuse of information by home governments, for example, to discriminate against disfavored groups. This concern might be better addressed through internal nondiscrimination law backed up by international human rights norms. To ban the exchange of tax information is an overly broad shield against discrimination.

These limitations serve the standard of democratic accountability for the exercise of sovereign discretion. They ensure that a nation only taxes the income of constituents, in the case of portfolio income, or the income of business operations that employ constituents, in the case of business income. Foreign investors have no formal role in a nation's legislative process. Furthermore, these limitations on the design of national tax codes lead us to consider exemption systems for

65. See Roin, supra note 48, at 597-99. 
business income and worldwide systems for portfolio income. We turn to those kinds of tax systems next.

\section{(a) Exemption Systems for Business Income}

These limitations on taxation suggest that nations should adopt exemption systems for the taxation of international business income. ${ }^{66}$ Under an exemption system, a nation does not tax the income generated by the foreign operations of its resident entities, whether those operations are conducted as branches or subsidiaries. ${ }^{67}$ A nation does tax the business income generated by a domestic business operation, regardless of whether the operation is conducted by a resident or a nonresident entity. ${ }^{68}$ The tax concept of a permanent establishment can be used to define an entity's business operations, both foreign and domestic. ${ }^{69}$

The limitations on taxation suggest that a nation should not have prescriptive jurisdiction over the income generated by its resident entities' foreign business operations. Such business income should remain within the exclusive prescriptive jurisdiction of the foreign nation. If such business income is distributed to the resident entity, the dividends should be exempt from taxation by the nation of residence; the underlying business income was within the prescriptive jurisdiction of the foreign nation. Dividends are distributions of the residual. ${ }^{70}$ Gain realized by the parent entity from the sale of stock in

66. Julie Roin would permit nations to impose a small tax on the income their resident entities derive from their foreign operations in recognition of the services provided by a home nation in the form of diplomatic protection and representation in international trade negotiations. See id., at 586-90.

67. There are several variants of an exemption system in existence today. For a concise account, see Hugh J. Ault \& Brian J. ARnOld, Comparative InCOME TAXATION 372-77 (1997). Terrence Chorvat points out that a deferral system functions much like an exemption system. See Terrence R. Chorvat, Ending the Taxation of Foreign Business Income, 42 ARIZ. L. REV. 835, 843-44 (2000) (citing David Hartman, Tax Policy and Foreign Direct Investment, 26 J. PUB. ECON. 187 (1985) and Hans Werner Sinn, Taxation and the Birth of Foreign Subsidiaries, in Trade Welfare And Economic Policies (Horst Herberg \& Ngo Van Long eds., 1993)).

68. A tax on business income could be converted into a consumption tax. See Barker, supra note 30, at 212-14. Michael Graetz believes that consumption taxes can be imposed "in a manner quite similar to income taxes," which may make GATT's distinction between direct taxes and indirect taxes meaningless. See Graetz, supra note 59, at 261, 298-99.

69. Business operations conducted on the high seas or in space may be difficult to allocate to a specific nation's economic environment. A multinational tax treaty could assist us here, perhaps by allocating the income from such operations among the markets served. Until the advent of a multinational tax treaty, such income might be treated under individual nations' anti-abuse regimes. Anti-abuse regimes are discussed in part IV.A.1 infra.

70. If, under an anti-abuse regime, shareholders with a small holding are not taxed currently by their jurisdiction of residence on their share of a controlled foreign corporation's 
a foreign corporation should also be exempt from taxation by the entity's jurisdiction of residence. Such gain reflects the accumulation of earnings exempt from taxation. Gain realized by a foreign branch on the sale of assets producing exempt income should also be exempt from taxation by the parent entity's jurisdiction. Expenses allocable to foreign business operations would not be deductible in the jurisdiction of residence. ${ }^{71}$

Instead of distributing its residual, the foreign business operation might accumulate and employ the residual in its future operations. The nation of the parent entity's residence should not have taxing jurisdiction over the income generated by such capital accumulated by a foreign operation of one of its resident entities; such income lies within the exclusive prescriptive jurisdiction of the foreign nation. Such income includes royalties from the licensing of intellectual property developed by the foreign business operation, regardless of the source of those royalties.

The limitations counsel against nations taxing the income generated by the worldwide operations of their resident entities. Existing worldwide systems of taxation should be replaced by exemption systems. ${ }^{72}$ In particular, our goal of global economic development suggests that the United States should substitute an exemption system for its current worldwide system of business income taxation.

In addition to promoting our goal of global economic development, an exemption system avoids the pitfalls of worldwide systems of taxation. Worldwide systems of taxation inhibit sovereign

diverted portfolio income, the portion of their dividends attributable to such income must be taxable by their jurisdiction of residence. Anti-abuse regimes are discussed in part IV.A.1 infra.

71. Interest expense would have to be allocated on a worldwide basis. See Michael J. Graetz \& Paul W. Oosterhuis, Structuring an Exemption System for Foreign Income of U.S. Corporations, 54 NAT'L TAX J. 771, 781 (2001).

72. John Steines points out that an exemption system has repercussions for a nation with a classical system of two levels of tax on corporate income. If we were to exempt an individual's foreign business income from domestic taxation, we would also have to exempt distributions to a shareholder from a domestic corporation made out of its exempt foreign business income. See John P. Steines, Jr., Whether, When, and How to Tax the Profits of Controlled Foreign Corporations, 26 BROOK. J. INT'L L. 1595, 1601-02 n.8 (2001). The solution may be to tax the net amount of an individual's foreign business income as portfolio income. This would, in effect, impute a corporation between the foreign business income and the individual, exempt the corporation's foreign business income, and then treat the individual's income as a distribution from that corporation. 
competition in economic development. ${ }^{73}$ To make sovereign competition effective in economic development, the standards encourage private choice among national economic environments. To promote such choice, business income must be taxed at the location of the business operation. This permits private decision-makers to choose among nations' economic environments and to make the choice on the basis of their individual business segments. ${ }^{74}$

In addition, worldwide systems of taxation depend on the concept of an entity's residence, which make the systems difficult to administer. Entities can manipulate the criteria for determining their residence. Such manipulation permits entities to choose among nations for their place of residence on the basis of tax rates alone rather than on the basis of economic environments. This results in entities relocating their formal place of residence to headquarters tax havens. ${ }^{75}$ Furthermore, establishing an entity's residence on the basis of the residence of its owners is impractical for publicly held entities. ${ }^{76}$

(b) Worldwide Systems for Portfolio Income

The limitations on taxation suggest that nations should have worldwide systems of taxation for the portfolio income of their resident investors. Nations ought not to impose a tax on the portfolio income of foreign investors. ${ }^{77}$ A national tax code should not offer a foreign tax credit for portfolio income. ${ }^{78}$ If a business entity transfers

73. See C. Gustafson et Al., TAXATiOn OF InTERnational TrAnsactions 19-20 (3d ed., 2006) (describing worldwide tax systems with a foreign tax credit neutralizing effect of low foreign tax rates).

74. The taxation of an entity's business income solely on the basis of residence leads to the odd result that a developing nation providing infrastructure to production facilities might not collect any tax at all. To develop tax revenues from business operations under a residence-based system, a developing nation would have to become a headquarters tax haven.

75. See Avi-Yonah, Globalization, supra note 52, at 1573, 1593-97.

76. Robert Green has suggested the alternative of imputing a publicly held entity's income to its shareholders, which might avoid the need to determine the nationality of the entity. See Robert A. Green, The Future of Source-Based Taxation of the Income of Multinational Enterprises, 79 CORNELL L. REV. 18, 70-74 (1993). Such imputation may be particularly difficult to administer. See id.at 72; Reuven S. Avi-Yonah, The Structure of International Taxation: A Proposal for Simplification, 74 TEX. L. REV. 1301, 1313 (1996) [hereinafter Avi-Yonah, Simplification].

77. Michael Graetz and Itai Grinberg would eliminate withholding taxes on foreign portfolio income and push for multilateral arrangements for improving taxpayer compliance with residence-based tax on portfolio income. Michael J. Graetz \& Itai Grinberg, Taxing International Portfolio Income, 56 TAX L. REV. 537, 578-85 (2003).

78. Under the baseline established by the limitations on taxation, a foreign tax credit would constitute a capital export subsidy. Furthermore, a foreign tax credit permits the nation of importation to determine the amount of the subsidy (subject to market conditions and the terms 
capital to a foreign branch, the nation in which the capital was formed may impute a return on such capital. An investor's nation of residence should have prescriptive jurisdiction over gain realized on the investor's disposition of an investment.

Worldwide systems for the taxation of portfolio income do not inhibit sovereign competition to the degree that worldwide systems for the taxation of business income do. ${ }^{79}$ The location of international portfolio investment is primarily dependent on risk and return, rather than on a nation's economic environment. Sovereign competition in shaping economic environments is unlikely to affect the location of portfolio investment.

Furthermore, international capital markets make it difficult for a nation to tax the portfolio income of foreign investors. Depending on the global demand for debt capital, it may be difficult for a nation, as a matter of market conditions, to tax the interest income of foreign investors at all or to maintain the source-based taxation of portfolio income generally. This inability to tax the interest income of foreign investors has justified to some observers the residence-based taxation of worldwide interest income, if not of all portfolio income, so that all such income is in fact taxed. ${ }^{80}$

of tax treaties), which would make the economic decision-making of the capital exporting nation indeterminate. Michael Graetz and Itai Grinberg would substitute a deduction for foreign taxes for the foreign tax credit when it comes to foreign portfolio investment. Graetz \& Grinberg, supra note 77, at 568-75. Gary Hufbauer and Joanna van Rooij would condition any deduction for foreign income taxes paid on the source country instituting a reporting system for dividends to the residence country. See GARY C. HUFBAUER \& JOANNA M. VAN ROOIJ, U.S. TAXATION OF INTERNATIONAL INCOME: BLUEPRINT FOR REFORM 66-68 (1992). If the United States adopted an exemption system for the taxation of business income but retained a credit system for portfolio income, its foreign tax credit could be simplified. Because foreign nations typically tax foreign investors' business income more heavily than their portfolio income, only lightly taxed income of U.S. investors would remain for crediting. Hence, the United States would be able to reduce the number of baskets necessary for the proper operation of a foreign tax credit limitation. See Steines, supra note 72, at 1605.

79. Residence-based taxation of the portfolio income of individuals may also be justified on the basis of equity, or redistributive possibilities. See Avi-Yonah, Simplification, supra note 76 , at 1316,1336 . The redistribution of wealth can be based on economic considerations, as well as equity: redistribution may affect the rate of economic development.

80. See Avi-Yonah, Globalization, supra note 52, at 1579-86, 1667-70. Forms of capital other than debt capital - equity, real property, tangible personal property, and intangible property - have different degrees of mobility than debt capital. (Intangibles are highly mobile in the sense that they can be withdrawn easily from a jurisdiction at the end of the licensing term. Their consumption is non-rivalrous, however, so higher returns elsewhere do not necessarily mean the intangibles would be withdrawn from a jurisdiction yielding a lower return.) It is more feasible for source jurisdictions to tax the returns from those forms of capital than the returns on debt capital. 
Recall that the standards for the exercise of sovereign discretion require national income tax codes to conform to norms of tax neutrality. ${ }^{81}$ We would achieve true capital export neutrality, or neutrality in the worldwide allocation of the supply of capital, if each nation had exclusive prescriptive jurisdiction over the portfolio income of its resident investors. ${ }^{82}$ Each investor would be subject to uniform worldwide taxation of its portfolio income, because such income would be taxable by only one nation and by that nation no matter where the investor puts the capital to use. ${ }^{83}$ True capital export neutrality allocates capital to the uses with the highest pre-tax riskadjusted returns, all other things (including economic environments) being equal.

Worldwide systems for the taxation of portfolio income still retain the problems of the manipulation by taxpayers of the criteria for residence and the failure by taxpayers to report their foreign portfolio income. These remaining problems are taken up later in this Article when it turns to problems of collective action.

3.Distinguishing Between Business Income and Portfolio Income

The distinction between business income and portfolio income is mainly one of the decision-making authority of the taxpayer. The taxpayer derives business income when it has direct control over the activities that create the cash flow that can be distributed to those making investments in the enterprise. ${ }^{84}$ Portfolio income is the

81. See supra Pt. III.B.3.

82. See Barker, supra note 30, at 195. Capital export neutrality is discussed in part III.D.1 infra.

83. The case of individual investors is more complicated, but its analysis reaches the same conclusion. Affluent individuals must decide how much of their after-tax income to save and how much to consume. This decision, and by extension, the supply of savings, is affected by the rate of return on savings. The policy of capital import neutrality would address this prior decision by affluent individual investors and is said to maximize world savings. Once affluent individuals have determined the amount of their savings, they then must decide upon the allocation of those savings among possible investments. The policy of capital export neutrality addresses this second decision. When these two policies conflict, Thomas Horst argues that the policy of capital export neutrality should be our choice because the demand for capital is more elastic than the supply of capital with regard to the rate of return. See Barker, supra note 30, at 191 (citing Thomas Horst, A Note on the Optimal Taxation of International Investment Income, 94 Q.J. ECON. 793, 793-96 (1980)). Barker believes that the policy of capital import neutrality does not in fact have an effect on the individual investor's decision to save or consume after-tax income, which would eliminate the policy as an alternative. See id. at 191-92.

84. Roger Gordon and Joosung Jun draw a similar distinction between portfolio financing and parent equity financing for a foreign operation. Parent equity financing (which, in my terminology, generates business income) allows joint control and operation in the home and 
distributed cash flow received by those investors. Business income is not a return on a factor of production; it is the residual or created value of the business operation. ${ }^{85}$

Portfolio investors have only indirect control over the activities that create the cash flow out of which they are to be paid. Although an investor may restrict an enterprise's discretion through contractual covenants, nevertheless the investor must be satisfied with acting indirectly through the enterprise's decision-makers, bearing a layer of agency costs not borne by the enterprise. ${ }^{86}$

The difference in the decision-making authority of the taxpayer leads to a difference in the manner in which investments are selected. The location of international direct investment exploits the investor's proprietary know-how or its economies of scale or scope. The location of international portfolio investment, on the other hand, is primarily dependent on risk and return. ${ }^{87}$

To foster global economic development, nations must focus on the decision-making authority of those with direct control of the activities that create the cash flow out of which investment returns, employee compensation, and taxes are paid. We would expect nations to shape their economic environments to influence those decisionmakers. The taxation of business income is an important component of a nation's economic environment.

host nations, but portfolio financing affects only the ownership of the foreign operation's income. Roger Gordon \& Joosung Jun, Taxes and the Form of Ownership of Foreign Corporate Equity, in STUDIES IN INTERNATIONAL TAXATION 13 (A. Giovannini et al., eds., 1993).

85. See Barker, supra note 30, at 195. Michael Devereux and Glenn Hubbard refer to this residual as economic rent, that is, a return in excess of a firm's cost of capital. The firm's intangibles, company-specific cost advantages, and economies of scale associated with its headquarter activities can be the source of such returns. See Michael P. Devereux \& R. Glenn Hubbard, Taxing Multinationals (Nat'l Bureau of Econ. Research, Working Paper No. 7920, 2000); R. Glenn Hubbard, Tax Policy and International Competitiveness, 82 TAXES 213, 218 (Mar. 2004) (treating economic rent as distinguishing foreign direct investment from portfolio investment).

86. Companies derive either business income or portfolio income from their working capital, depending whether such capital is employed in the business or is temporarily idle. For ease of administration and compliance, we might want to categorize the income from working capital as business income for tax purposes, subject to a limitation on the amount of the entity's working capital. Michael Graetz and Paul Oosterhuis would use a de minimis rule based on gross income or total assets. See Graetz \& Oosterhuis, supra note 71, at 775.

87. Foreign direct investment is said to complement domestic investment, as enterprises expand to exploit economies of scale or scope or to exploit their proprietary know-how. See Graetz \& Grinberg, supra note 77, at 549 \& nn.50-51. In contrast, foreign portfolio investment is said to substitute for domestic investment, with its location primarily dependent on risk and return. $I d$. at $549 \&$ nn.54-55. 
4. The Special Case of Intangibles.

Intellectual property, or intangibles, presents a special case for three reasons. First, the consumption of intangibles is non-rivalrous; the use of an intangible in a foreign jurisdiction doesn't necessarily prevent its use in the home jurisdiction. For that reason, the policy of locational or capital export neutrality isn't a consideration in the taxation of royalties from intangibles. The owner of intangibles isn't faced with the question of choosing among national economic environments for the allocation of its capital.

Second, a multinational enterprise frequently exploits its intangibles entirely in-house, without licensing the intangibles to outsiders. Transaction cost economics suggests that the companies that engage in foreign direct investment are technically innovative and cannot safeguard their intangibles through long-term contracts. ${ }^{88}$ To exploit their intangibles, such companies must own the foreign operations that make use of their intangibles. Those companies derive imputed royalty income, rather than arms-length royalty income.

Intangibles present a special case in a third sense. National governments frequently permit taxpayers to expense the costs of developing intangibles when those costs ordinarily would be capitalized. Governments subsidize the development of intangibles through this tax expenditure and arguably are entitled to receive the deferred tax revenue from the intangible's income stream as a result. Note that the expense incurred by the taxpayer in developing an intangible reflects the intangible's potential global return. The government that subsidized the development of the intangible for global use thus is arguably entitled to include the intangible's global royalties in its tax base. Conversely, a government should not tax the royalties from intangibles developed abroad. Such taxation arguably would be discriminatory, because the government did not subsidize the development of those intangibles. ${ }^{89} \mathrm{We}$ could view government subsidization of the development of intangibles partly as a public investment in a nation's economic environment and partly as an investment in the government's future stream of tax revenue.

This Article's treatment of portfolio income is consistent with this view of intangibles. Under that treatment, the worldwide returns on intangibles are properly taxable by the nation in which the intangibles were developed (and possibly subsidized). Royalties

88. See WiLliamson, Institutions, supra note 15, at 290-94, 296.

89. See Barker, supra note 30, at 208-09. 
would be deductible in the nation where the intellectual property is used and would not be subject to a withholding tax.

\section{The Returns on Foreign Direct Investment}

The limitations on prescriptive jurisdiction over the global income tax base have repercussions for the taxation of the returns on foreign direct investment. Recall that the limitations leave business income with the nation in which the underlying business operation is located. Such business income is the residual after the returns on capital have been paid and reflects in part the contribution made by a nation's economic environment. Because of the value to global economic development of sovereign competition and the other benefits of using multiple sovereigns, this residual should be exempt from further taxation when it is distributed to a parent corporation. Hence, the parent corporation would be entitled to a deduction for intercorporate dividends. ${ }^{90}$

Interest, rent, and royalties paid to a parent corporation would be deductible in the nation of source and taxable in the nation in which the underlying capital was accumulated, the same treatment these returns would receive when they are paid to unrelated persons. The nation of source ought not to impose a withholding tax on payments of dividends, interest, rent, or royalties. The limitations permit the nation of source to tax the underlying income out of which dividends are paid, while reserving the other items to the nation in which the underlying capital was accumulated. National tax codes would be entitled to impute a return on assets, intangibles, and borrowed funds made available by a resident entity to a foreign branch.

The limitations on prescriptive jurisdiction over the global income tax base do not relieve the pressure on national tax administrators to distinguish between true dividends and disguised interest, rent, or royalties or to distinguish between true interest, rent, or royalties and disguised dividends. National tax codes would need to police income-shifting and income-extracting techniques through anti-abuse rules. National tax codes would also have to police the use of corporations by individuals as passive investment vehicles.

90. Dividends paid to holders of small shareholdings would be subject to taxation if such shareholders' nation of residence employs a classical system of coordination between corporate and shareholder income taxes. 
6. Preferential Tax Regimes and Illicit Tax Competition.

Preferential tax regimes are an illicit form of sovereign competition. Preferential tax regimes offer tax rates to new business operations owned by non-residents that are lower than the tax rates in force for business operations owned by residents. Pressure from internal interest groups frequently requires a preferential tax regime to be ring-fenced: the beneficiary cannot deal in the sovereign's internal market but must export its products or services. Ring-fenced preferential regimes subsidize exports and thus violate this Article's limitation prohibiting export subsidies. ${ }^{91}$ Preferential tax regimes that are not ring-fenced may affect the relative prices of goods and services within a sovereign's economic environment and thus violate

91. Preferential tax regimes that subsidize exports of goods violate GATT. See Joel Slemrod \& Reuven Avi-Yonah, (How) Should Trade Agreements Deal with Income Tax Issues?, 55 TAX L. REV. 533, 550 (2002) (referring to production tax havens); Reuven S. Avi-Yonah, Treating Tax Issues Through Trade Regimes, 26 BROOK. J. INT'L L. 1683, 1686-87 (2001) [hereinafter Avi-Yonah, Treating]. The OECD report suggests that ring-fenced tax incentive regimes are detrimental to global economic growth; such regimes are said to fall outside the "standard tax-revenue paradigm." See Engel, supra note 59, at 1577, n.279. Another export subsidy may lie within a nation's source rules if the nation uses a foreign tax credit system. For example, the United States uses a set fifty-fifty division between manufacturing and sales income for products manufactured domestically and then exported from the United States; the United States then characterizes the sales income as foreign source. See Treas. Reg. § 1.863-3(b) (as amended in 1998). The sales income is not taxed by the country of importation if the taxpayer has no permanent establishment in that country, but is eligible for cross-crediting of foreign income taxes for purposes of the U.S. foreign tax credit. The result for U.S.-based multinational enterprises with operations in high-tax jurisdictions is that fifty percent of U.S. export income is not taxed by anyone. See CHARLES I. KInGSON, InTERnATIONAL TAXATION 49-60 (1998); Claire Kelly et al., Panel Transcript IV, 26 BROOK. J. INT'L L. 1711, 1716 (2001) (remarks by Charles I. Kingson). To the extent that export income is not taxed by anyone, it benefits from an export subsidy in violation of GATT. Reuven Avi-Yonah sees possible export subsidies in the tax regimes of traditional tax havens and headquarters tax havens. See AviYonah, Treating, supra note 91, at 1687-88. I disagree, although such tax havens may run afoul of other standards and limitations presented by this Article. Traditional tax havens have no income tax for either residents or foreign investors. Even if such tax havens prohibit foreign investors from providing financial services to residents, such ring-fencing is not an export subsidy. Instead, such ring-fencing is a form of market segmentation, which raises prices to residents in their purchases of services. It may also violate the national treatment standard for services under the General Agreement on Trade in Services. Headquarters tax havens do have an income tax, but do not tax the income derived by a resident company from its foreign subsidiaries. As long as those exemption systems are properly structured (that is, so as not to exclude export income from domestic operations but only to exclude income attributable to foreign permanent establishments), the systems should pass muster under GATT and under the standards and limitations developed in this Article. Avi-Yonah would find an export subsidy when an exemption system excluded foreign source income that was not taxed by the source country. Id. at 1688 . 
this Article's standard requiring neutrality in tax legislation. ${ }^{92}$ Accordingly, preferential tax regimes exceed the institutional competence of a nation. ${ }^{93}$ To attract branches and subsidiaries of nonresidents without abusing its sovereign discretion, a nation must lower its tax rate for all business operations, regardless of ownership. ${ }^{94} \mathrm{We}$ might refer to this conclusion as the tax norm of national treatment for foreign-owned business activity: business activity owned by foreign investors should be treated no better and no worse than business activity owned by domestic investors.

\section{Evaluation of Two Traditional Policies}

Analysts traditionally have used the policies of capital export neutrality and capital import neutrality to evaluate rules of international taxation. ${ }^{95}$ Neither policy fully takes into account the institutional competence of nations in global economic development. If we subordinate these two traditional policies to our goal of global economic development and take institutional competence into account, we can eliminate capital import neutrality from consideration and confine the application of capital export neutrality to capital income only.

92. The standards for legislation are discussed in part III.B.3 supra. The effects of a preferential tax regime on the sponsoring nation include a possible increase in imports of goods and services (which balances the inflow of capital and is caused by capital inflows increasing the value of the local currency) and a possible decrease in exports of goods and services produced by existing, locally owned businesses. Requiring the foreign-owned business to be conducted in a foreign currency may shield the sponsoring nation from some of the externalities. See Barker, supra note 30 , at 178 . Labor costs for locally owned businesses might increase, depending on initial unemployment and the role of exports in the local economy.

93. Reuven Avi-Yonah sees preferential tax regimes as a form of tax competition that does not reflect voter choice about the size of a nation's government. Preferential tax regimes are frequently created by administrative action without voter approval. See Avi-Yonah, Globalization, supra note 52, at 1627-28. Preferential tax regimes may also be unjustified on the basis of cost-benefit analysis. See id. at 1628 . He would therefore distinguish preferential tax regimes from regimes with universally low rates. $I d$. at 1627-28. Preferential tax regimes may be the result of a collective action problem; because of competition, no nation feels that it can dispense with them when bidding for new foreign investment. See id. at 1645-46.

94. Julie Roin would permit a small differential between the tax rates for domestic taxpayers and for foreign taxpayers to reflect the costs incurred by the government in extending representation in international trade matters and diplomatic protection to domestic taxpayers under international law. See Roin, supra note 48, at 590-92. To avoid creating an incentive for domestic companies to expatriate, Roin would maintain identical tax rates for foreign and domestic corporations, and transfer the differential to the taxation of domestic shareholders. See id. at 591-92.

95. See GUSTAFSON, supra note 73, at 17-18. 


\section{Capital Export Neutrality}

The policy of capital export neutrality asks a sovereign to consider the combination of the nation's tax code with those of other nations and to design the domestic code in such a way as to remove aggregate taxation as a consideration in a resident enterprise's choice of location for a business operation. ${ }^{96}$ The policy is usually implemented by the adoption of a tax code that taxes a nation's residents on the income from their worldwide operations, with a credit for foreign income taxes they have paid on their foreign income up to the amount of domestic tax owed on that foreign income. In effect, a nation tops off the foreign income tax on its residents' income from foreign operations to bring the aggregate tax burden up to the level borne by the income from domestic operations. ${ }^{97}$

The policy of capital export neutrality is inconsistent with this Article's first limitation on a nation's prescriptive jurisdiction over the global tax base. ${ }^{98}$ The first limitation provides that a nation may not exercise prescriptive jurisdiction over the income arising from business operations conducted within the territory of another nation; a nation's prescriptive jurisdiction over the income arising from business operations conducted within its own territory is to be exclusive. Under the first limitation, a nation may not impose a topping off tax on the income arising from its residents' business operations conducted in other nations.

Capital export neutrality is, however, consistent in result with this Article's second limitation on a nation's prescriptive jurisdiction. The second limitation provides that a nation has exclusive prescriptive jurisdiction over the worldwide portfolio income of its residents; a nation may not exercise prescriptive jurisdiction over any of the portfolio income of another nation's residents. The second limitation provides the locational neutrality that serves as the motivation for the policy of capital export neutrality, but for portfolio investment only.

96. Id.

97. In practice, the policy of capital export neutrality is not implemented fully. For example, a resident enterprise may elect to eliminate the domestic tax by incorporating its foreign operations as foreign subsidiaries and repatriating only those earnings for which it has sufficient foreign tax credits to eliminate the domestic tax.

98. See supra Part III.C.2 for the three limitations on a nation's prescriptive jurisdiction suggested by this Article. 
The policy of capital export neutrality is usually justified on the grounds of allocative efficiency. ${ }^{99}$ Giving nations exclusive prescriptive jurisdiction over the income arising from business operations conducted within their own territory is said to be inefficient, in the sense of skewing decisions about the location for business operations. Enterprises should not choose the location for new business operations on the basis of low tax rates, so the policy argues, but instead on the basis of non-tax factors. ${ }^{100}$ The policy would neutralize not only the attraction of a foreign nation's lower tax rate, but would neutralize the difference between two foreign nations' lower tax rates.

The justification for the policy is incomplete. It fails to take into account the difference between allocative efficiency and adaptive efficiency. Allocative efficiency addresses the maximum output possible for an economy, given a particular institutional arrangement (including the initial distribution of endowments). ${ }^{101}$ Allocative efficiency ties together a particular institutional arrangement and a particular maximum output, as it were. The maximum output possible with one institutional arrangement of an economy may well differ from the maximum output that is possible with another institutional arrangement for that economy. This raises the question of determining and selecting the institutional arrangement that produces the greatest maximum output for an economy. Adaptive efficiency addresses the changes in an economy's institutional arrangement that permit the economy to achieve a higher maximum output. Adaptive efficiency helps a society over time to grow economic output larger

99. For a survey of limitations of the economic analysis supporting the policy of capital export neutrality, see Graetz, supra note 59, at 284-93. Reuven Avi-Yonah has a helpful account of commentary by economists on capital export neutrality, Avi-Yonah, Globalization, supra note 52, at 1604-11, as well as welfare economics and public choice, id. at 1611-16.

100. Even within a single national economic environment, locational neutrality might not be the optimal policy. As Daniel Shaviro has said, "The argument for locationally neutral taxation . . . is ... that absent differences on the service side taxes should be neutral and minimize behavioral responses." Shaviro, supra note 58, at 909. Locational neutrality fails to take into account the "differences on the services side." See Charles Tiebout, A Pure Theory of Local Expenditures, 64 J. POL. ECON. 416 (1956) (advancing the thesis that free movement of persons between cities with different levels of taxes and services will maximize the satisfaction of preferences). In addition to differences in services, there may be differences in institutional environment.

101. See NORTH, supra note 2, at 28 ("with positive transaction costs, resource allocations are altered by property rights structures"); Ronald H. Coase, The Problem of Social Cost, 3 J.L. \& ECON. 1 (1960). 
than the maximum produced by allocative efficiency at any given time. ${ }^{102}$

We cannot determine the best institutional arrangement a priori, in part because of the cognitive limitations of decision-makers (including the withholding of information by others). Instead, we must allow societies to develop different institutional arrangements and evaluate them by comparison. ${ }^{103}$ The policy of capital export neutrality fails to take into account this necessity of having multiple and autonomous decision-makers, the different economic environments offered by nations, and the role of competition in limiting abuses of sovereign discretion.

When applied to foreign business operations, the policy of capital export neutrality imposes a negative externality on nations by distorting the effect of their decisions about tax rates and capital formation and imposing an additional tax burden on their economies. If one nation imposes a topping off tax on the income generated by a resident's business operation located in a second nation, the effective tax rate in the second nation on business income will be higher, the

102. See NORTH, supra note 2, at 80-82; Pavel Pelikan, The Formation of Incentive Systems in Different Economic Systems, in INCENTIVES AND ECONOMIC SYSTEMS 27, 31-33 (Stephan Hedlund ed., 1987) (comparing organizational processes to allocative processes). Oliver Williamson refers to allocative efficiency as a form of second-order economizing. See WILLIAMSON, MECHANISMS, supra note 2, at 94 ("Marginal analysis is typically concerned with second-order refinements to the neglect of first-order economizing."). Second-order economizing is subordinate to first-order economizing, which deals with the efficiency of organizations and institutional environments. See id. at 100 ("[e]conomics was too preoccupied with issues of allocative efficiency, in which marginal analysis was featured, to the neglect of organizational efficiency, in which discrete structural alternatives were brought under scrutiny."), 309-11. The relationship between international law and domestic law runs into an analogous problem. Efficient domestic rules may come at the expense of efficient rules about prescriptive jurisdiction. See Trachtman, supra note 28 , at 30 . In a similar vein, Joel Trachtman asserts that "conflicts efficiency may override substantive efficiency, just as conflicts justice may override substantive justice ... . The question of what law to apply becomes a fundamental question of justice among overlapping communities and overlapping substantive goals." Id. at 42 (citing Gerhard Kegel, Fundamental Approaches, in 3 INTERNATIONAL ENCYCLOPEDIA OF COMPARATIVE LAW, ch. 3, at 4-5 (Kurt Lipstein ed., 1987)). Nancy Kaufman points out the need to separate the concerns of international law from those of domestic law in the analysis of fairness in taxation. Fairness within a national tax code deals with the distribution among a population of the burden of a nation's revenue needs. Fairness as a criterion of international taxation is a characteristic of the allocation among nations of the competence to tax. Nancy $\mathrm{H}$. Kaufman, Fairness and the Taxation of International Income, 29 LAW \& POL'Y INT'L BUS. 145, 155-56, 202 (1998). In contrast, Cliff Fleming, Bob Peroni, and Steve Shay would apply the same concept of fairness - interpersonal equity - at both the national and international levels. J. Clifton Fleming, Jr. et al., Fairness in International Taxation: The Ability-to-Pay Case for Taxing Worldwide Income, 5 FLA. TAX REV. 299 (2001).

103. See supra Pt. II. 
possible rate of capital formation lower, and the level of future tax revenue lower than the second nation had determined. The second nation is left with the unsatisfactory alternative of raising its tax rate and, via the mechanism of the first nation's foreign tax credit, regaining the tax revenue burdening its economy.

The justification for the policy of capital export neutrality is incomplete in a second sense. The policy views foreign direct investment as a transfer of net savings between nations and thus a substitute for domestic business investment. The policy fails to consider foreign direct investment that extends a resident enterprise's application of proprietary intangibles to take advantage of economies of scale and scope and thus serves as a complement to domestic business investment. ${ }^{104}$ More specifically, the justification fails to take into account the economic benefits of transferring the ownership of existing business assets to new owners who can use the assets more productively. ${ }^{105}$

In contrast, foreign portfolio investment is a transfer of net savings and thus a better candidate than foreign direct investment for the application of the policy of capital export neutrality. Decisions about the location of foreign portfolio investment are driven by riskadjusted return and not by the differences among national economic environments. This Article does not, however, adopt the underpinnings of the policy. Instead, this Article's second limitation on a nation's prescriptive jurisdiction is based on the need for capital formation and the concomitant need to assure national decisionmakers that capital formed through lower tax rates will generate income within the nation's future tax base. The second limitation addresses the incentives facing national decision-makers.

At times, the policy of capital export neutrality serves as a rationalization of self-interest. The policy inhibits competition among sovereigns in the creation of national economic environments, a key measure to contain the agency costs of the delegation of decision-

104. See Mihir A. Desai \& James R. Hines, Evaluating International Tax Reform, 56 NAT'L TAX J. 487, 488-91 (2003). Institutional economics explains why a resident enterprise cannot simply exploit its proprietary intangibles through contracts with independent local enterprises in the foreign market. Contracts cannot give the resident enterprise the necessary control over its intangibles; common ownership of the foreign enterprise and the resident enterprise is required for such control. Multinational enterprises exist in part to exploit proprietary intangibles that cannot be protected under contracts with independent third parties. See WiLliamson, INSTITUTIONS, supra note 15, at 290-94.

105. See Desai \& Hines, supra note 94, at 494-96. Mihir Desai and James Hines elaborate on this insight by proposing the international tax policy of capital ownership neutrality. See id. 
making authority to sovereigns by the world's people. The policy serves the self-interest of a nation's public decision-makers by limiting competition in taxation and any short-term reduction in a nation's tax revenues. In addition, domestic interest groups may view the policy as a way to segment global markets along national lines. In that sense, the policy of capital export neutrality serves protectionist ends. The policy is a blunt instrument for addressing the costs of transition to higher standards of living by means of the international movement of business operations. The policy addresses those transition costs by attempting to prevent the movement in the first place, rather than by evaluating the distribution of the benefits from freer trade. ${ }^{106}$

\section{Capital Import Neutrality}

The other traditional policy for the evaluation of international tax rules is capital import neutrality, or private competitiveness. Capital import neutrality asks a sovereign to recognize a right of each of its resident enterprises to compete in foreign markets under the same aggregate tax burden as its foreign competitors. ${ }^{107} \mathrm{~A}$ nation usually implements the policy through the adoption of an exemption system for the taxation of income derived from its residents' foreign operations. Income derived from a resident's foreign operation is exempt from taxation, regardless of whether the operation is conducted as a branch or through a foreign subsidiary. The resident's income from its foreign operation bears only the tax imposed by the foreign nation. In contrast, income derived by a resident from a domestic business operation, whether the income is of foreign source or domestic source, is taxed by the resident's nation.

The policy of capital import neutrality coincides in result with this Article's first limitation on a nation's prescriptive jurisdiction over the global tax base. The first limitation provides that a nation may not tax the income arising from business operations conducted within the territory of another nation; each nation is to have exclusive prescriptive jurisdiction over income derived from operations conducted within its territory. The basis for the first limitation, however, is not a concern for the foreign competitiveness of national champions, but rather a concern for global economic development.

106. Targeted assistance programs may be less expensive in the long run than restrictions on trade. For a discussion, see Alan O. Sykes, Countervailing Duty Law: An Economic Perspective, 89 COLUM. L. REV. 199, 211-13 (1989).

107. See GUSTAFSON, supra note 73 , at 18. 
The policy of capital import neutrality is not consistent with this Article's second limitation on a nation's prescriptive jurisdiction over the global income tax base. The second limitation provides that a nation is to have exclusive prescriptive jurisdiction over the worldwide portfolio income of its residents. Because different nations may well impose different rates of tax on the portfolio income of their residents, income derived by foreign investors from portfolio investment in a single nation may be subject to different rates of tax. Thus, a portfolio investor would not invest in a foreign nation under the same tax burden as competing investors.

There are two traditional justifications for the policy of capital import neutrality. Neither takes into account the institutional competence of nations in global economic development. The first seeks efficiency in the allocation of a foreign market's demand for capital. This justification has been discredited. The justification wrongly assumed that the elasticity of the supply of capital was greater than the elasticity of the demand for capital in response to changes in taxation. ${ }^{108}$ The justification also required that each nation tax the income derived by foreign portfolio investors in the same manner as it taxed the income of domestic portfolio investors. ${ }^{109}$ The international mobility of capital, however, prevents most nations from adopting this approach. ${ }^{110}$

The second traditional justification for the policy appeals to the fairness of treatment of a resident enterprise and its competitors in foreign markets. The topping off tax imposed by a nation with a worldwide tax system, so the argument goes, places an additional burden on its enterprises as they compete in a foreign marketplace against enterprises subject to no such additional tax.

108. See Barker, supra note 30, at 191-92.

109. See id. at 193.

110. Competitive conditions in capital markets may prevent a nation from taxing the interest income of foreign investors at all or from maintaining the source-based taxation of portfolio income generally. See Avi-Yonah, Globalization, supra note 52, at 1579-86. Furthermore, in a small, open economy, the burden of a withholding tax on interest income would not fall on the foreign lender's shareholders. Instead, the burden would be passed on to the domestic borrower who must then do two things: reduce its demand for borrowings and reduce its fixed domestic costs, for example, its wage bill. This is the basis for the recommendation that small, open economies not tax investment income, but tax labor directly (which is more efficient than taxing labor indirectly through the withholding tax on investment income). See Roger H. Gordon \& James R. Hines Jr., International Taxation, 4-5 (Nat'l Bureau of Econ. Research, Working Paper No. 8854, 2002). 
The justification based on fairness attracts two kinds of criticism. The first kind is based on the incidence of a corporate income tax. Capital import neutrality assumes that the incidence of a domestic corporate income tax falls on consumers in the foreign market and thus affects the competitive position of the enterprise in the foreign market. ${ }^{111}$ Traditionally, however, the incidence of a corporate income tax was thought to fall on the corporation's shareholders. Proponents of capital export neutrality used this traditional understanding to criticize the policy of capital import neutrality on two grounds. First, a topping-off tax by the corporation's home nation would only affect its shareholders' return on their investment, reducing the corporation's capitalization in a one-time event but not otherwise affecting the corporation's competitive position. ${ }^{112}$ The corporation pays the topping-off tax only when it is profitable; its break-even point should not be affected by a corporate income tax. Second, the corporation's foreign competitors would have no incentive to lower prices in the foreign marketplace, because such a strategy would only lower their own profit margin. ${ }^{113}$

More recent scholarship suggests that shareholders share the burden of a corporate income tax with consumers and workers. ${ }^{114}$ This conclusion suggests that a topping-off tax may in fact reduce competition in the foreign market place, to the detriment of consumer welfare ${ }^{115}$ Furthermore, GATT decisions that characterize targeted income tax subsidies as export subsidies also assume that a

111. See Peggy B. Musgrave, United States taxation of Foreign Investment INCOME 119 (1969).

112. See Joseph A. Pechman, Federal Tax Policy 144 (5th ed. 1987).

113. This argument is an extension of the argument that the policy of taxing nonprofit organizations on their unrelated business income is misconceived. For the latter argument, see Susan Rose-Ackerman, Unfair Competition and Corporate Income Taxation, 34 STAN. L. REV. 1017 (1982); Richard Steinberg, "Unfair" Competition by Nonprofits and Tax Policy, 44 NAT'L TAX J. 351 (1991). The extension of the argument fails to take into account a for-profit organization's reduction in its own profit margin as a strategy to gain market share.

114. See Pechman, supra note 112, at 141-46. In a closed economy, the burden of a corporate income tax falls primarily on capital owners. However, in a small, open economy, the burden of a withholding tax on interest income does not fall on the lender's shareholders. Instead, the burden is passed on to the borrower who must then do two things: reduce its demand for borrowings and reduce its fixed domestic costs, for example, its wage bill. This is the basis for the recommendation that small, open economies not tax investment income, but tax labor directly (which is more efficient than taxing labor indirectly through the withholding tax on investment income). See Gordon \& Hines, supra note 110, at 4-5.

115. One effect of a topping off tax could be a reduced variety of goods available to the global market. See Joel B. Slemrod, Free Trade Taxation and Protectionist Taxation, 2 INT'L TAX \& PUB. FIN. 471, 483 (1995) (referring to such a reduction as an efficiency cost). 
corporate income tax of a home nation affects the workings of foreign markets and not simply the return enjoyed by the shareholders of an enterprise. GATT outlaws export subsidies because they skew competition within the market of importation. ${ }^{116}$

The justification based on fairness attracts a second kind of criticism. This criticism targets the justification's over-inclusiveness. Consider the income arising from the domestic operations of resident enterprises. Taken to its logical conclusion and without regard to the institutional competence of nations, a policy of fairness for national champions requires that the income arising from a domestic operation's export sales be excluded from domestic taxation if foreign competitors conduct their operations within an economic environment less burdensome than the domestic economic environment. ${ }^{117}$ The thrust of the policy is to neutralize some element in the domestic economic environment so as to eliminate that element as a competitive factor in the resident enterprise's global industry. In this instance, capital import neutrality would be a form of illicit competition by a sovereign. The elimination of a valid element in the domestic economic environment for the benefit of exporters of goods or services but not for anyone else in the domestic constituency is a form of export subsidy, i.e., a form of discrimination that impairs global economic development. The policy of capital import neutrality simply becomes a rationalization of the self-interest of national champions in avoiding elements of the national economic environment in which they conduct their operations.

The institutional competence of nations provides a better foundation for exemption systems of taxation for foreign business operations. Global welfare benefits from multiple sovereigns, different national economic environments, and sovereign competition. Exemption systems improve competition in a host nation's markets and respect the host nation's decisions about capital

116. Paul McDaniel identifies three negative effects of export subsidies, including those distributed through tax subsidies: the skewing of sales away from third-country producers who have a comparative advantage over the subsidized producers, the missed opportunity by the subsidized producers to achieve new efficiencies, and possible retaliation by third countries through competing subsidies. See McDaniel, Trade Agreements, supra note 56, at 295. Export subsidies may also increase the value of the subsidizing nation's currency, reducing the benefit of the subsidy without reducing its cost to the nation's taxpayers. See id. at 296.

117. As yet, no one has argued that the domestic sales income of a resident enterprise should be exempt from domestic taxation if its products or services compete with imports. The protectionist impulse is expressed through countervailing duties, antidumping duties, or safeguard measures. 
formation by all enterprises active in its economic environment. ${ }^{118}$ The institutional competence of nations in global economic development limits the use of the policy of capital import neutrality to business operations. Furthermore, it limits the policy to the income derived by a resident enterprise from a foreign operation and thus limits the overly broad nature of the policy's justification based on fairness.

\section{COLLECTIVE ACTION PROBLEMS}

Nations face problems in collective action as they shape their economic environments. A collective action problem leads a nation to choose an inferior state of affairs because it cannot rely on other nations to make the choices necessary for all to achieve a superior state of affairs. In a collective action problem, the parties' self-interest is insufficient to coordinate their choices and achieve the optimum result. We are concerned with those collective action problems that prevent nations from achieving strong economic development and cause them to settle for less.

\section{A. Social Norms as the Solution}

We solve collective action problems by changing the consequences of the alternatives faced by decision-makers and by that means coordinating their decision-making. ${ }^{119}$ Although there are several ways to change the consequences of a sovereign decisionmaker's alternatives, the use of social norms must be the primary method. ${ }^{120}$

118. A worldwide system of taxation for business income serves as a unilateral projection of a nation's conception of economic development onto the world. See Brown, supra note 59, at 313-14 (discussing the OECD's lack of attention to the needs of developing nations and referring to "the hegemony of the principle of capital export neutrality").

119. For an elaboration of this point, see DOUGLAS G. BAIRD ET AL., GAME THEORY AND THE LAW 31-35 (1994).

120. I define the term "social norm" broadly to include behavioral regularities that maximize value for actors in cooperative relationships. I differ from Eric Posner, who sometimes limits the denotation of the term to behavioral regularities that signal an actor's trustworthiness in cooperative relationships and departures from which cause the actor to be shunned by others. See ERIC A. POSNER, LAW AND SOCIAL NORMS 34 (2000) (distinguishing social norms from "behavioral regularities that emerge in cooperative relationships simply because they are value maximizing"). I agree with Posner that any behavioral regularity that arises from incomplete information is a social norm. See id. at 41. An actor might continue its cooperative behavior in the face of incomplete information about its payoff in a particular round of an indefinitely repeated game in the belief that cooperation maximizes the actor's payoffs through all rounds of play. 
In general, there are five ways to coordinate decision-making about economic development: markets; longer-term relationships achieved through bargaining; voting that is binding on dissenters; hierarchy, i.e., the grant of asymmetric and incompletely defined authority to one decision-maker to direct the decision-making of another; and social norms. ${ }^{121}$ The first four ways are of limited use for the coordination of sovereign decision-making.

We have already mentioned competition among sovereigns as a means of limiting the abuse of sovereign discretion. The market in sovereigns, if you will, suffers from almost prohibitive transaction costs; individuals are unable to move easily among sovereigns. The resulting segmentation of the market impairs its ability to coordinate sovereign decision-making. Furthermore, markets are of limited use under conditions of asymmetric information and interdependent work. Under those conditions, markets must be supplemented by shared knowledge and cooperation. Those supplements can be created through hierarchy and social norms. ${ }^{122}$

Bargaining to create a longer-term relationship between decision-makers is a second method of coordinating decision-making. Nations enter into treaties to stabilize their expectations of each other's behavior. Bargains, however, require hierarchy for their enforcement when the norms they contain are not self-enforcing. Furthermore, bargaining can be inefficient in the face of asymmetric information and stalemate over the division of the efficiency bonus. There are no incentive schemes to which parties will agree voluntarily that will cause parties to disclose their payoffs. ${ }^{123}$ Those incentive schemes must be imposed through hierarchy and social norms.

Voting that is binding on dissenters is a third method of coordinating decision-making. Such voting is generally unavailable in a world of sovereign decision-makers, although binding voting mechanisms are found in some international organizations such as the European Union. ${ }^{124}$ Even when binding voting is available, Arrow's Theorem tells us about the shortcomings of such voting as a means of coordinating decision-makers. For voting to retain both Pareto

121. This definition of hierarchy comes from MILLER, supra note 6, at 16 .

122. See MiLler, supra note 6, at 8-13, 57, 216-18.

123. See id. at 47-50 (citing Roger B. Myerson \& Mark A. Satterthwaite, Efficient Mechanisms for Bilateral Trading, 29 J. ECON. THEORY 265 (1983)).

124. For voting mechanisms that bind dissenting states with the European Union, see J. Dinnage \& J. Murphy, The Constitutional LAW of The European Union 26 (2d ed. 2008) (qualified majority voting by member states). 
optimality and coherence (i.e., the transitivity of collective choices) in the coordination of decision-making, we must restrict the range of voter preferences. ${ }^{125}$ In general, we can restrict the preferences of decision-makers through incentives, through screening the decisionmakers whom we admit to the voting process, and through social norms. Incentives, however, can be impractical to use because of their expense. ${ }^{126}$ Screening decision-makers can only be done if we are willing to coordinate international decision-making on less than a global basis. Social norms may be the only means of limiting preferences among sovereign decision-makers.

Hierarchy is unavailable as a means of coordinating decisionmaking in a world of sovereign decision-makers. We have no central decision-maker who exercises authority over nations. Without hierarchy, we cannot set up enforcement mechanisms for markets, bargains, or voting. Nor can we set up proper incentive systems to elicit otherwise hidden action and hidden information or to restrict the range of preferences. Without hierarchy, we must rely on social norms alone to complete the coordination of decision-making by markets, bargaining, and voting.

Thus, international social norms are an important part of the solution to international collective action problems. Social norms are a means of fostering shared knowledge and cooperative behavior in order to improve global economic development. Unaided by hierarchy, social norms must carry a heavy burden.

The lack of a central authority over nations has five ramifications for the use of social norms to coordinate international decisionmaking in economic development. First, we have no need to create vertical norms of commitment; without a central authority, sovereign decision-makers need not fear that their decision-making authority will be appropriated by the center. Second, we cannot create vertical norms of reciprocal cooperation and thus cannot use such vertical norms to foster the development of horizontal social norms. Third, we

125. This is the Sen Paradox. See Miller, supra note 6, at 86-89 (citing Amartya SEN, Collective Choice And Social Welfare (1970); Amartya Sen, Liberty, Unanimity, and Rights, 43 ECONOMICA 217 (1976); Amartya Sen, Liberty and Social Choice, 80 J. PHIL. 5 (1983)).

126. See Bengt Holmstrom, Moral Hazard in Teams, 13 BeLL J. ECON. 324 (1982) (noting that the cost of incentives to employees outweighs the benefit of increased productivity); see also Peter Klibanoff \& Jonathan Morduch, Decentralization, Externalities, and Efficiency, 62 REV. ECON. STUD. 223, 231-35 (1995) (discussing possibility that the cost of inducement exceeds the benefit of coordination among actors, thus challenging the design by a central authority of a reward and punishment system intended to induce their cooperation). 
cannot create property rights that facilitate the creation of appropriate horizontal social norms. Nations must create those norms without the benefit of property rights set by a central authority. ${ }^{127}$ Fourth, we cannot enforce horizontal norms, once they arise, by a hierarchy. Fifth, without a central authority, we can model the collective action problems of nations by repeated game theory.

The appropriate social norms will extend the time horizon of nations as decision-makers. The appropriate norms include norms of reciprocated cooperation and reciprocated effort; the norms must address externalities and hidden action in inter-dependent work. The norms must also address the problem of hidden knowledge; a nation may need information to enforce its laws that is possessed by another nation.

Social norms that coordinate sovereign decision-making in our pursuit of global economic development become part of the standards and limitations we develop for the exercise of sovereign discretion. The standards for and limitations on the design of national economic environments are social norms, and they counter both abuses of sovereign discretion and international collective action problems.

\section{Anti-Deferral Regimes}

A national income tax code generally does not tax a resident entity's foreign subsidiaries. At most, a tax code waits until the subsidiaries distribute their income to the resident entity and taxes the income at that time. The tax code is said to defer the taxation of a foreign subsidiary's income until the income is repatriated. An antideferral regime is a set of provisions in a national tax code that overrides the deferral of tax on the income of foreign subsidiaries. When the regime applies, the tax code taxes the income of foreign subsidiaries to the resident entity without delay.

Anti-deferral regimes are said to embody a dilemma. When they apply and tax the income of foreign subsidiaries currently, the regimes advance a policy of tax neutrality in the choice of location in which to conduct a business operation, either domestic or foreign, and in the choice of entity, either a subsidiary or a branch. When the antideferral regimes do not apply and the national tax codes defer the taxation of the income of foreign subsidiaries, the regimes advance a

127. For an elaboration of the use of property rights by a central authority to foster horizontal social norms, see MILLER, supra note 6, at 211 (discussing management created property rights for self-directed work teams in order to foster the development of good horizontal norms within those work teams). 
policy of promoting the competitiveness of foreign subsidiaries in their marketplaces. The two policies of tax neutrality and competitiveness are said to be irreconcilable, with the anti-deferral regime being a pawn in the battle between advocates of the two policies.

The dilemma is only apparent, however. Once we recall that our overall goal is the well-being of the world's people, and once we realize that global economic development is necessary to achieve that goal, the dilemma falls away. Global economic development becomes the higher objective that orders the relationship between warring policies. Our objective of global economic development calls for a set of autonomous decision-makers on the same plane of authority, serves as a brief for those decision-makers, and sets standards for and limitations on the exercise of their discretion. Those standards and limitations specify the general outlines of national tax codes to minimize the exploitation of individuals and to reduce opportunism in international relations. The brief for global economic development and the set of standards and limitations partly define the competence of nations.

Recall the primary norms that the standards and limitations suggest for the international taxation of business and investment income. For business income, a nation may tax only the income from business operations conducted within its own economic environment. A nation is not to tax the income of foreign branches and subsidiaries. Furthermore, a nation is to apply uniform rates of taxation to all business income and not grant preferential rates to the income of foreign-owned business operations. For portfolio income, a nation may tax the worldwide investment income of its residents. A nation is not to tax the portfolio income of foreign investors.

What function do anti-deferral regimes serve under these norms of international taxation? In particular, does the adoption of exemption systems of taxation for business income eliminate the need for anti-deferral regimes? No. When our goal is global economic development, anti-deferral regimes define impermissible tax avoidance and solve collective action problems in the enforcement of national tax law. From this point of view, anti-deferral regimes are a species of anti-avoidance regime. A nation's anti-deferral regime supports its taxpayers' compliance with their national tax code and, by solving collective action problems in the enforcement of other nations' tax codes, supports compliance with those other tax codes. 
Anti-deferral regimes have five functions to serve. First, the regimes must police the diversion of business income from its economic environment to another taxing jurisdiction. Thus, incomeextractive arrangements and income-shifting arrangements are properly within the ambit of anti-deferral regimes. Second, antideferral regimes must police attempts to change the apparent residence of an investor through the interposition of an entity between the investor and its portfolio income. As a result, incomeholding arrangements and the taxation of income from liquid passive assets would also fall within the ambit of anti-deferral regimes. Third, anti-deferral regimes may be used to neutralize the effect of preferential tax regimes. ${ }^{128}$ Fourth, anti-deferral regimes may address the income from business operations that are difficult to allocate to any nation's economic environment. The income from the operation of highly mobile business assets, such as ships or satellites, would fall within the scope of anti-deferral regimes. Fifth, for nations with classical systems of corporate and individual income taxation, antideferral regimes may police the de facto distribution of profits without the declaration of a formal dividend or through the sale of the shareholder's investment in the multinational enterprise. ${ }^{129}$ Some of these functions address collective action problems themselves, while others, perhaps all, give rise to collective action problems in their enforcement. The first two of these functions are discussed below.

A nation's anti-deferral regime may take any of several forms. Some nations target income subject to a low rate of foreign tax..$^{130}$ Others target income that arises in a nation appearing on their list of suspect jurisdictions. ${ }^{131}$ Two nations use neither a tax rate nor a list of nations, but instead identify income by the type of transaction giving

128. See discussion of an anti-deferral regime infra Part IV.B.1(a).

129. In the United States, these matters are addressed by sections 956 and 1248 of the Internal Revenue Code. I.R.C. §§ 956, 1248 (2006).

130. For example, Japan's anti-deferral system uses a low rate of foreign tax to identify income subject to current taxation. See Yoshihiro Masui, Comment: A Japanese View, 52 SMU L. REV. 541, 543 (1999).

131. David Rosenbloom proposes the converse of this approach for the United States. Under his approach, all income of foreign subsidiaries of American multinational enterprises would be taxed currently except for income arising in a list of nations with well-developed tax systems. See Rosenbloom, supra note 54, at 1535-39, 1544-46. 
rise to the income..$^{132}$ Nations that do not use a low rate of tax to identify potentially diverted income may apply a high-tax kickout, that is, exempting income from their anti-deferral regimes if it was subject to a high rate of foreign tax. There are other possible structures. ${ }^{133}$

\section{(a) The Diversion of Business Income}

The standards and limitations suggest that business income ought to fall within the exclusive taxing jurisdiction of the nation in whose economic environment the underlying business operation was conducted. Taxpayers, however, may attempt to shift the apparent origin of their business income away from its economic environment to a lower-tax jurisdiction. Their attempts may be categorized as either income-extracting arrangements or income-shifting arrangements.

Income-extracting arrangements rely on intercorporate deductions within the multinational group to extract income from the high-tax jurisdictions in which it was earned and reposition the income in lower-tax jurisdictions. Income is paid out as deductible interest, rent, or royalties. Subsidiaries are capitalized mainly with debt and are leased or licensed the assets necessary for their operations. A single business might be unbundled into separate activities and divided among different tax jurisdictions. For example, a business' intellectual property can be segregated into a separate entity charged with managing the income stream thus created from in-house licensing fees. Recalling the separation of a vacuum into matter and anti-matter, some taxpayers create paired but completely

132. In informal remarks, Philip West has commented that, of all the nations with an antideferral regime, only Canada and the United States do not tie the regime to a list of countries or a tax rate. Panel Transcript III, 26 BROOK. J. INT'L L. 1611, 1616 (2001).

133. John Steines would structure the United States anti-deferral regime as a minimum tax on the income of foreign subsidiaries. U.S. shareholders could credit whatever foreign taxes were paid by the controlled foreign corporation against the U.S. minimum tax. When the income was repatriated, U.S. shareholders would receive a credit for both the foreign tax and the residual U.S. minimum tax. See Steines, supra note 72, at 1606 . Steines notes that several other countries employ a minimum tax approach. Id. Robert Peroni, Cliff Fleming, and Stephen Shay advocate the domestic taxation of a multinational enterprise's worldwide income and would deny in all cases the deferral of taxation of the income of foreign subsidiaries. They advocate a flow-through model of taxation for the income of foreign subsidiaries rather than an imputed dividend model. Under a flow-through model, losses and the underlying character of income flow through to the shareholder. A deduction for host-country income taxes is not created. Peroni, Fleming, and Shay would not retain a minimum ownership requirement. See Robert J. Peroni et al., Getting Serious About Curtailing Deferral of U.S. Tax on Foreign Source Income, 52 SMU L. REV. 455, 507-12 (1999). 
offsetting risks within a corporate family and, through derivative contracts between family members, divert income from one jurisdiction to another. A tax haven company might be used as an intermediate holding company to receive dividends and deductible payments.

National tax codes counter income-extracting arrangements by limiting the deductions and deferral necessary for the extractive techniques to work. For example, cross-border interest deductions might be limited for thinly capitalized subsidiaries. ${ }^{134}$ Interest payments might be recharacterized as non-deductible dividends. Or, the income of an intermediate holding company might be imputed to the ultimate parent company.

Income-shifting arrangements, on the other hand, usually employ simple transfer pricing abuse. Transactions with outside customers or clients are booked to tax haven entities even though the work producing the income from those transactions is performed by other entities in higher-tax jurisdictions. Income shifting arrangements are illustrated well by the facts of the Du Pont case..$^{135}$ Du Pont created a Swiss subsidiary to handle its European marketing and sales. Du Pont would sell products to the Swiss subsidiary, which in turn would sell the products to independent European distributors. By design, the transfer pricing Du Pont used with its Swiss subsidiary was to leave the lion's share of the combined companies' profit in Switzerland. Switzerland had a preferential tax regime that taxed the Swiss subsidiary's income only lightly. Because of the transfer pricing used, the Swiss subsidiary's income included part of the parent's manufacturing income as well as the parent's sales income.

National tax codes counter income-shifting arrangements by limiting the transfer pricing and deferral necessary for the techniques to work. Tax administrators might reallocate income away from the tax haven entity to better reflect the relative contributions of related entities to the completion of a contract. Or, the income booked to tax haven subsidiaries might be imputed to the ultimate parent company.

Transfer-pricing rules frequently are ineffective. Rules that are based on arms-length pricing among entities are stymied by the contributions of proprietary intangibles and group economies in

134. The U.S. tax code accomplishes this through the earnings-stripping rules of section 163. See I.R.C. § 163(j) (2006).

135. Du Pont de Nemours \& Co. v. United States, 608 F.2d 445 (Ct. Cls. 1979). This preSubpart F case arose under Code section 482. Id. at 446. 
transaction costs. ${ }^{136}$ Profit-split methods are more realistic, but encounter problems as nations use inconsistent formulas. Antideferral regimes exist in part because of the significant problems with transfer pricing rules. By imputing the income of a foreign subsidiary to a parent company, an anti-deferral regime creates quite roughly a consolidated entity.

Unfortunately, anti-deferral regimes are unsatisfactory as well. Anti-deferral regimes are necessarily blunt weapons, overriding the uncertainties of transfer pricing and subjective intent. As blunt weapons, however, they capture and penalize ordinary business arrangements made by the unwary. For example, the anti-deferral rules that target the income shifted to regional holding companies also capture ordinary intercorporate loans and leases. Just as with transfer-pricing rules, we have problems with the inconsistent treatment of income by nations. Anti-deferral regimes also can be quite complex, leading to an unanticipated interplay with other taxing provisions. $^{137}$

Furthermore, anti-deferral regimes fall victim to a serious collective action problem. International law allocates among nations general prescriptive jurisdiction over companies in such a way that a nation may apply its anti-deferral regime only against its own multinational groups. A nation cannot apply its anti-deferral regime against transfer pricing abuses of a foreign-based multinational enterprise, even though it might affect its own tax collections from the domestic member of the group. This limitation requires each nation to impede income-shifting arrangements of its own multinational groups that affect other nations' tax bases, even when the arrangements do not affect its own tax base.

For example, the United States' anti-deferral regime cannot reach diversionary transactions between the subsidiaries of a German parent corporation, one of which is incorporated within the United States. At most, the United States can use its transfer pricing rules

136. Accurate transfer pricing would also reflect the degree of decentralization at the organization and the attendant incentive structure for division managers. Bengt Holmstrom \& Jean Tirole, Transfer Pricing and Organizational Form, 7 J. L. ECON. \& ORG. 201, 202-03 (1991).

137. According to Charles Kingson, U.S. multinational enterprises can now avoid two important features of the U.S. anti-deferral regime by the use of that nation's check-the-box regulations: the inclusion within foreign personal holding company income of intra-group returns from non-portfolio investment and the inclusion of income from transactions with foreign related persons. Charles I. Kingson, Leonardo da Vinci and the 861 Regulations, 26 BROOK. J. INT’L L. 1565, 1569-70 (2001). 
and provisions for the denial of deductions. Only the nation with prescriptive jurisdiction over the parent corporation can apply its anti-deferral regime to the entities controlled by the parent. The United States must depend on Germany's anti-deferral regime to back up the American transfer pricing rules. Conversely, Germany must rely on the United States' anti-deferral regime to back up its transfer pricing rules in the case of transactions to which a German subsidiary of a United States parent corporation is a party.

Not all nations will institute anti-deferral regimes. Nations wanting to attract the parent companies of multinational enterprises as residents will refrain from doing so. Multinational enterprises can then avoid anti-deferral regimes through the use of such headquarters tax havens. ${ }^{138}$ Changing the definition of residence might not solve the problem of the expatriation of companies to headquarters tax havens. ${ }^{139}$

The formulary apportionment of a multinational group's income among nations would solve the problem of expatriation by eliminating the need for the concept of corporate residence. Furthermore, ideal formulary apportionment would eliminate the need for international transfer pricing rules and the need for antideferral regimes to address income-shifting transactions. We will consider formulary apportionment shortly, after we examine the use of anti-deferral regimes to counter the diversion of portfolio income.

(b) The Diversion of Portfolio Income

The standards and limitations suggest that portfolio income ought to fall within the exclusive prescriptive jurisdiction of the nation of which the investor is a resident. The investor's nation of residence is entitled to tax the investor's worldwide portfolio income. However, an investor might transfer her portfolio investment assets to an entity resident in another nation in an attempt to take advantage of the other nation's lower tax rates on investment income. The arrangement diverts portfolio income away from the investor and into a holding entity owned by the investor. Nations thwart this maneuver by means of their anti-deferral regimes. The entity's portfolio income is imputed to the investor, or the investor is charged interest until the investor repatriates the income. The appreciation in value of the investment assets might also be taxed to the investor at

138. See Avi-Yonah, Globalization, supra note 52, at 1665-66.

139. Id. 
the time the investor initially transfers the assets out of the jurisdiction.

Unfortunately, an investor may mask her identity through the use of a conduit tax haven and thus avoid the exchange-ofinformation obligations between the nation paying the portfolio income and the investor's nation of residence. ${ }^{140}$

2. Formulary Apportionment

A foundation for international taxation must allocate business income derived by a multinational enterprise among the nations in which the enterprise operates. The standards for and limitations on the exercise of sovereign discretion have already suggested that nations should adopt exemption systems for the taxation of international business income. Exemption systems require that business income be allocated among nations on the basis of the location of the business operation that generated the income.

Traditionally, an enterprise's business income has been allocated among nations according to rules classifying the income according to type; rules based on that classification that identify the nations that are the source of the income; rules that allocate deductions among nations; rules that define the presence of a business operation, or permanent establishment, in a nation; and rules that attribute types of income to a permanent establishment. Rules of transfer pricing correct the division of income among related taxpayers. Additional rules govern the manner in which income is taxed by a nation once the income is identified with a particular nation. Such rules of classification, source, permanent establishment, and attribution are adjusted by the terms of tax treaties, when a treaty applies.

The traditional approach assumes that a multinational enterprise is a collection of legally separate entities that operate and are managed autonomously. Each subsidiary operates a separate business and frequently in only one nation, is managed independently from the other formal entities within the multinational enterprise, and deals with those other entities at arm's length, as if those entities conducted independent businesses. Branches, if they exist, are frequently imagined to be separate entities. The rules are geared to legal entities and, moreover, to legal entities that operate, and are managed, distinctly from one another.

140. See id. at 1665. Infra Pt. IV.B.2 proposes a secondary norm of international taxation to respond to this problem. 
The traditional approach fails to appreciate the economics of organization for many multinational enterprises. First, the multinational enterprise is not a collection of independently managed subsidiaries dealing with one another at arm's length. The competitive advantage of the complex organization over a collection of independent actors in the market place is the organization's ability, through hierarchy, to reduce the transaction costs incurred by the loose collection of market actors. ${ }^{141}$ Arms-length transfer pricing misses the income attributable to the enterprise's ability to reduce the transaction costs of the marketplace. ${ }^{142}$

Second, one of the transaction costs reduced by the multinational form of enterprise is the cost of protecting intangibles through licensing agreements with outside persons. When the terms of licensing agreements cannot protect an enterprise's intangibles at reasonable cost, the entity itself must undertake the international use of its intangibles. ${ }^{143}$ This in-house use of intangibles makes transfer pricing difficult; the unique nature of intangibles make comparisons difficult for purposes of pricing.

Third, the structure of the management of a multinational enterprise's operations does not follow the structure of its ownership of its subsidiaries. It is true that a multinational enterprise must delegate decision-making authority to autonomous actors, subject to standards and limitations. However, the multi-divisional form that the management of a multinational enterprise usually takes groups sets of subsidiaries together and operates them in an integrated fashion. ${ }^{144}$ The internal reporting of the multinational enterprise follows the management structure rather than the ownership structure. The entity-specific accounting of the enterprise can be an afterthought.

Thus, transfer pricing is a serious problem for the traditional approach. The operations of a multinational enterprise may be easily attributed to specific nations, but the income of those operations might not. The traditional approach also encounters the problem of

141. See Ronald H. CoAse, The Firm, the Market, AND the LaW 38-40 (1988).

142. See Reuven S. Avi-Yonah, The Rise and Fall of Arms-Length Pricing, 15 VA. TAX REV. 89, 148-49 (1995).

143. See Williamson, InSTITUTIONS, supra note 15, at 290-94, 296 (discussing the suggestion by transaction cost economics that foreign direct investment is made by companies that are technically innovative and that cannot safeguard their intangibles through long-term contracts).

144. See id. (explaining that the foreign subsidiary is managed as part of a single multidivisional enterprise, not as an autonomous subsidiary). 
inconsistent national rules for defining permanent establishments, classifying income, identifying the source of income, and attributing income to permanent establishments. Tax treaties give bilateral solutions to the definition of permanent establishments, and advance pricing agreements give limited relief for the problem of transfer pricing, but the other problems remain.

In principle, a promising approach is the formulary apportionment of a multinational enterprise's income among the nations in which it operates. Such an approach determines the aggregate taxable income of a multinational enterprise and then allocates that income according to a formula among the nations in which its operations are located. ${ }^{145}$ The participating nations must agree on the factors taken into account by the formula and the weighting the factors are to have in the formula. One approach would allocate income among nations on the basis of sales, labor costs, assets, and research and development costs. ${ }^{146}$ The inclusion of research and development costs would capture the contribution of

145. Formulary apportionment in effect attributes a multinational enterprise's residual income (in the transfer pricing sense) to all of the factors used as variables in the formula. Because an enterprise's residual income reflects, among other things, its return from reducing the transaction costs encountered by a group of independent actors in the marketplace, such treatment of an enterprise's residual income is preferable to one that attributes all of the residual income to a single factor. For example, the U.S. profit-split method allocates all residual income to a company's intangibles. See Treas. Reg. § 1.482-6(c)(3)(i)(B).

146. See Graetz, supra note 59, at 319-20. For another proposal for international formulary apportionment, see Avi-Yonah, Simplificaion, supra note 76, at 1348-49. The proposal to include sales as a factor in the apportioning formula would permit a nation in which the enterprise sells its products or services without a sales operation to tax part of the enterprise's income. This contrasts with the traditional approach, which requires a sales operation or other permanent establishment in a nation before the nation may tax the sales income of a non-resident enterprise. Several commentators have argued that the domestic consumption of imported goods and services should be a basis for a nation's taxation of income. Stephen Shay, Cliff Fleming, and Robert Peroni argue that a source-based tax can be justified as the price of access to a nation's markets. Stephen E. Shay et al., "What's Source Got to Do With It?" Source Rules and U.S. International Taxation, 56 TAX L. REV. 81, 91-93 (2002). Michael Graetz puts it differently. He first points out that "consumption taxes may be imposed in a manner quite similar to income taxes." Graetz, supra note 59, at 299 (citing Michael Graetz, International Aspects of Fundamental Tax Restructuring: Practice or Principle?, 51 U. MiAmi L. REV. 1093, 1097-98 (1997)). Because of this, he believes that a nation that hosts a market for a product but not a sales operation may have a claim to tax the income derived from sales in its market. Id. Reuven Avi-Yonah also calls for the allocation of income to consuming nations for purposes of income taxation. Avi-Yonah, Globalization, supra note 52, at 1670-75; Reuven S. Avi-Yonah, International Taxation of Electronic Commerce, 52 TAX L. REV. 507, 544-45 (1997). Avi-Yonah would enforce the consuming nation's taxation of the sales income of an enterprise that had no sales operation within its jurisdiction by means of a withholding tax on sales. Avi-Yonah, Globalization, supra note 52, at 1672-74. 
intangibles to the production of the enterprise's income. ${ }^{147}$ The portfolio income earned by a corporation could be added to its business income and taxed by source, that is, by apportioning the income among nations according to an international formula. ${ }^{148}$

Formulary apportionment would eliminate the need for rules governing transfer pricing, the classification of income, the determination of the source of income, and the residence of a corporation. $^{149}$ By eliminating the need to determine a corporation's residence, formulary apportionment addresses the vulnerability of anti-deferral regimes to the expatriation of parent companies to headquarters tax havens. Furthermore, formulary apportionment would eliminate the need to track inter-corporate payments within the multinational enterprise. Moreover, formulary apportionment could be used to define the concept of permanent establishment. ${ }^{150} \mathrm{~A}$ permanent establishment could be deemed to exist in a nation if the formula allocates to that nation more than a pre-determined amount of the enterprise's income. Below that amount, de minimis by definition, a nation would not tax the enterprise on its income. ${ }^{151}$ Formulary apportionment coupled with exemption systems would also permit the elimination of the foreign tax credit, parts of antideferral regimes, the branch profits tax, and the earnings stripping rule. $^{152}$

Formulary apportionment must be implemented on a multilateral basis. Enterprises are unlikely to agree to formulary apportionment unless all nations in which an enterprise operates participate and do so on a uniform basis. For the simplest multinational enterprises, formulary apportionment could be

147. See Graetz, supra note 59, at 317.

148. See Avi-Yonah, Simplification, supra note 76, at 1353. Avi-Yonah would tax passive foreign investment companies (foreign mutual funds, generally) on the basis of source, however, as if they were banks or other financial institutions. See id. at 1354.

149. Taxing business income at source, rather than on the basis of residence, reduces the need to establish the residence of a corporation. See Graetz, supra note 59, at 323 (eliminating the benefit to a multinational enterprise of manipulating its residence, by apportioning its income among nations according to a formula).

150. See id. at 319-20.

151. Reuven Avi-Yonah would define a permanent establishment as a minimum level of sales into a jurisdiction. Avi-Yonah, Globalization, supra note 52, at 1671.

152. See Avi-Yonah, Simplification, supra note 76, at 1354-55. On the basis of his specific proposals, Avi-Yonah would eliminate the Subpart F and PFIC provisions, but retain the FPHC provisions. See id. 
introduced through advance pricing agreements, to which typically only two nations are party.

Unfortunately, the implementation of formulary apportionment runs into a virtually insurmountable problem. Participating nations must agree on a common definition of the enterprise's taxable income. This requires agreement on the definitions of gross income and deductions and the treatment of losses. In particular, participating nations must agree on depreciation schedules for the enterprise. In effect, formulary apportionment requires harmonization of national tax codes, a task open to anti-competitive abuse and requiring Herculean effort. ${ }^{153}$

Without formulary apportionment, we are left with the traditional approach to exemption systems, which require the attribution of income to permanent establishments. Losses would not be deductible unless they were attributable to the permanent establishment.

\section{Tax Treaties}

Tax treaties are a means of solving collective action problems through the conscious creation of social norms. Tax treaties adjust the allocation among nations of prescriptive jurisdiction over the global tax base through the coordination of primary norms of taxation and the withdrawal of secondary norms of taxation.

153. For a discussion of the challenges of harmonizing national tax codes, see Roin, supra note 48, at 594-97; see also Julie A. Roin, Taxation Without Coordination, 31 J. LEGAL STUD. S61 (2002); but see Yariv Brauner, An International Tax Regime in Crystallization, 56 TAx L. REV. 259, 262 (2003) (proposing a partial and gradual harmonization of nations' international tax rules other than their tax rates). The inter-governmental debates required for tax harmonization may lead to the compromise of different apportioning formulas for different industries. There are other challenges in the implementation of formulary apportionment. First, nations would have to agree on whether the apportioning formula is to be applied separately to an enterprise's separate businesses. To do so might re-introduce transfer pricing problems, as the income of the separate businesses is segregated. Second, corporate minority shareholders and pass-through entities, such as partnerships, raise the question of the sequence of apportioning income among nations and among participants in enterprises. It seems best to first apply formulary apportionment to the multinational enterprise's income and allocate its income among nations. Each nation may then apply its rules for the allocation of the income among partners or investors in the enterprise. In this approach, the nationality of the multinational enterprise is irrelevant, and no international consensus is needed on the permissible allocation of income among partners under each nation's tax code. A drawback of this approach is that the income of the controlling participant might be apportioned differently from the rest of its income, inviting the creation of partnerships simply to avoid the full effect of international formulary apportionment. 
Almost all tax treaties in existence today are bilateral. Most of these treaties are based on the common model sponsored by the Organization for Economic Cooperation and Development (OECD). The OECD model is a significant source of multilateral coordination in the exercise by nations of prescriptive jurisdiction over the global tax base. ${ }^{154}$ The use of multilateral treaties is taken up later in this Article. $^{155}$

Tax treaties can be analyzed in terms of transaction-cost economics. In general, transaction-cost economics aligns transactions with governance structures to economize on bounded rationality and to reduce transaction costs, including the costs of opportunism. ${ }^{156}$ Tax treaties serve as governance structures with regard to the parties' transactions in prescriptive jurisdiction. Tax treaties are enhanced versions of Williamson's hybrid governance structures, because the treaty partners cannot seek judicial intervention as a last resort but must rely entirely on the mechanisms they create in their treaties and on follow-up negotiations. ${ }^{157}$

In a sense, the partners to a tax treaty find themselves in a bilateral monopoly. They share a highly specific asset: the tax base of income flows that cross their common border. ${ }^{158}$ This analogy with a bilateral monopoly is not complete, however. If the partners cannot agree to a division of their common tax base, they will both use the entire shared tax base, which leads to over-taxation of their common asset. In this sense, the treaty partners share a two-person commons. Over-taxation may result in diminished returns for the two governments. $^{159}$

Tax treaties generally are used to limit the source-based taxation of investment income in favor of residence-based taxation, to eliminate source-based taxation of de minimis amounts of business income, to eliminate overlapping definitions of tax residence, and for the exchange of information about taxpayers. Tax treaties also

154. See Hugh J. Ault, The Importance of International Cooperation in Forging Tax Policy, 26 BROOK. J. INT’L L. 1693, 1694 (2001).

155. See infra Pt. IV.B.3.

156. See Williamson, Mechanisms, supra note 2, at 12 (the discriminating alignment hypothesis); WILLIAMSON, INSTITUTIONS, supra note 15, at 32, $72-79$ (economizing on bounded rationality and safeguarding against opportunism).

157. See Williamson, Mechanisms, supra note 2, at 10, 95-97; Williamson, INSTITUTIONS, supra note 15 , at 70-71.

158. See Williamson, Institutions, supra note 15 , at 52-56.

159. See Garrett Hardin, The Tragedy of the Commons, 162 SCIENCE 1243 (1968) (arguing that overuse of a commons leading to diminished returns for all users). 
contain nondiscrimination clauses. Such clauses prevent a nation's retaliation against non-treaty nations from affecting the enterprises of its treaty partners.

\section{B. The Enforcement of Social Norms}

Without a central authority to enforce social norms, we must rely on self-enforcing norms and norms of punishment. A self-enforcing social norm relies for its continued existence on each participant's belief that others will continue to observe the norm only as long as the participant observes the norm and that the benefits to the participant from the norm outweigh the costs. ${ }^{160}$ In this sense, social norms are mutually reinforcing expectations of others' behavior ${ }^{161}$ In a world of social convention, an actor must be concerned about the effect that its behavior has on others. In perfectly competitive markets, an actor cannot move the market, and hence its behavior has no effect on other participants.

Social norms that are not self-enforcing must rely on norms of punishment for their observance. Norms of punishment subject the offending nation to different treatment by other nations. To the extent that the standards for and limitations on sovereign discretion are not self-enforcing, we will need a second set of social norms that nations apply in their dealings with nations who fail to observe the standards and limitations. Different treatment would include retaliation through the imposition of externalities on those nations, externalities that would shift the balance among the offending nation's interest groups to favor compliance with the primary norms. The second set of norms change the offending nation's payoffs in

160. See MiLler, supra note 6, at 204. George Akerlof has applied the social conventions of gift exchange to labor contracts. See George A. Akerlof, Labor Contracts as Partial Gift Exchange, 97 Q. J. ECON. 543 (1982).

161. We might view the rules of customary international law as self-enforcing social norms. We can then screen purported rules of customary international law by asking whether nations' self-interest would cause the norm to be honored widely and repeatedly and whether nations have formed the belief that the compliance of others now depends on their own. Jack Goldsmith and Eric Posner see the traditional rules of customary international law as emerging from national self-interest in four strategic situations: the coincidence of interests, coercion, bilateral cooperation, and bilateral coordination. Jack L. Goldsmith \& Eric A. Posner, A Theory of Customary International Law, 66 U. CHI. L. REV. 1113, 1114-15 (1999). Multilateral cooperation and coordination through customary international law are unlikely in light of the assumptions necessary in game theory to explain such behavioral regularities as a function of self-interest. Id. at 1129-31; but see George Norman \& Joel P. Trachtman, The Customary International Law Game, 99 AM. J. INT'L L. 541 (2005) (showing that game theory can explain multilateral cooperation under certain circumstances). 
favor of the standards and limitations. This second set of social norms must be self-enforcing, that is, it must be in the self-interest of the enforcing nations to impose the norms of punishment in their dealings with an offending nation. ${ }^{162}$

The social norms embodied by the General Agreement on Tariffs and Trade (GATT) are illustrative. A primary norm of GATT forbids the use of export subsidies by member nations. In the event that a member nation enacts an export subsidy, other members may invoke a secondary norm: each member that imports subsidized goods from the offending member may impose a countervailing duty on those imports. The countervailing duty is limited; it cannot exceed the amount of the export subsidy. The permitted retaliation is measured, unlike the retaliation that might be imposed on a nonmember nation.

Thus, GATT envisions three levels of treatment for a nation. Member nations that respect the primary norm banning export subsidies see their exports flow unimpeded by countervailing duties. Member nations that subsidize their exports are subject to measured countervailing duties. Non-members that subsidize their exports are subject to arbitrary retaliation.

In contrast, tax treaties envision only two levels of treatment for a nation. Parties that abide by the terms of a tax treaty enjoy limitations on the foreign taxation of their residents' income. Parties that do not abide by the terms of a tax treaty or who are not parties to a tax treaty enjoy no such limitations. Tax treaties do not include norms of measured retaliation. Most tax treaties are bilateral; a multilateral tax treaty would permit us to create secondary norms of measured retaliation to enforce primary norms of international taxation.

The secondary norms of GATT are self-enforcing; interest groups within retaliating nations provide the pressure. We must only be concerned with retaliation that fails to remain within the bounds set by GATT. The pressure brought by interest groups on the national decision-makers of GATT members is so strong at times that

162. Douglas Heckathorn concludes that self-interested players are more likely to enforce norms of punishment than to observe first-order norms. See Douglas D. Heckathorn, Collective Action and the Second Order Free Rider Problem, 1 RATIONALITY \& SoC'Y 78 (1989). Credit markets also have a role to play in the enforcement of social norms. Norms embodied in loan agreements with the International Monetary Fund are indirectly enforced by the international market for sovereign debt, which will refuse to reschedule existing debt or extend additional credit to sovereigns in default of an IMF loan agreement. 
it threatens members' own compliance with GATT's primary norms. ${ }^{163}$

A mechanism for resolving disputes about appropriate levels of treatment can be advantageous in maintaining social norms. The dispute resolution mechanism of GATT is illustrative. GATT permits member nations to impose countervailing duties that conform to its terms. The European Union might have unilaterally imposed countervailing duties on imports from the United States to offset the export subsidies the union perceived in the U.S. tax code. Instead, GATT first required the European Union to protest the perceived export subsidies through the GATT dispute resolution mechanism. Such a protest ultimately brings an end to the dispute about whether the U.S. tax code violates a primary norm of GATT and prevents a subsequent dispute about the propriety of any countervailing duties.

Social norms and mechanisms for the resolution of disputes allow nations to form stable expectations about each other's behavior. Social norms extend each nation's area of rationality by increasing the range of alternatives that a sovereign can consider. The increased range of alternatives counters some of the inevitable incompleteness in making decisions. ${ }^{164}$ Arbitral decisions change the environment for sovereign decision-making, by directing an offending sovereign's attention in its law-making. In so doing, arbitral decisions assist in the integration of nations' behavior in the face of collective action problems. ${ }^{165}$

Three questions arise in the evaluation of any secondary norm. First, to what degree is the secondary norm self-enforcing, that is, how likely is it that other nations will impose the secondary norm? This question includes a consideration of the interest groups in a retaliating nation that would press for the application of the secondary norm. Second, to what extent will the secondary norm cause offending nations to comply with the primary norm? This question includes a consideration of the interest groups within the

163. Compare Certain Motor Vehicles and Certain Chassis and Bodies Therefor, USITC Pub. 11110, Inv. No. TA-201-44 (Dec. 1980) (determining that an economic recession was a greater cause of the U.S. automobile industry's economic problems than an increase in imports) with 19 U.S.C. $\$ 2252$ (c)(2)(A) (added by the Omnibus Trade and Competitiveness Act of 1988) (directing the ITC to splinter a recession into multiple causes to lessen a recession's importance relative to an increase in imports).

164. For the inevitable incompleteness of decision-making, see supra notes 18-24 and accompanying text.

165. Herbert Simon discusses the integration of behavior within a complex organization by changing the environment for decision-making. See SIMON, supra note 8, at 106-17. 
offending nation that would lobby for compliance with the primary norm once they come under pressure from the secondary norm. Third, compared to other candidates for a secondary norm, will the secondary norm do the least harm to our overall objective of global economic development for the well-being of the world's people?

1. Secondary Norms for the Taxation of Business Income

When a nation departs from the primary norms for the taxation of business income, what are the appropriate secondary norms for other nations to apply? As a response to a nation that enacts a preferential tax regime, other nations might be permitted to impose offsetting import duties on products and services exported by the offending nation. This secondary norm would require coordination with the norms of GATT. The appropriate response to a nation that taxes the income of its residents' foreign operations might be the denial to the offending nation of the benefits under a proposed multinational tax treaty of the exchange of information and exemption from other nations' default withholding taxes on portfolio income. These and other alternatives are discussed below.

\section{a. Countering Preferential Tax Regimes}

The standards and limitations require that a nation treat foreignowned business operations no better and no worse than locally owned business operations. We referred to this conclusion as the tax norm of national treatment for foreign-owned business activity. ${ }^{166}$ This primary tax norm would prohibit preferential tax regimes for foreign investment.

A foreign investor might elicit a preferential tax regime by its solicitation of bids from several nations for its investment. A nation might offer a preferential tax regime in order to match the bids made by other nations. An effective secondary norm would require nations to lower uncompetitive general tax rates to attract foreign investment, instead of offering preferential tax regimes available only to a foreign investor.

The appropriate secondary norm would offset the benefit of a preferential tax regime. There are two alternatives to consider. First, we could permit the foreign investor's home nation to tax the business income derived under a host nation's preferential tax regime. The home nation's rate of tax would be limited to the difference

166. See supra Pt. III.C.6. 
between the host nation's general rate of taxation and its preferential rate. This current taxation of foreign branches and subsidiaries operating under a preferential tax regime offsets the tax preference.

Would this proposed secondary norm be effective? Competitors in the retaliating nation should support the imposition of the secondary norm. In nations the social welfare system of which depends on an individual being employed, labor groups would be a second group supporting the secondary norm. What is unclear is whether the secondary norm would pressure the offending nation to change its behavior. No interest groups within the offending nation would be affected by this kind of retaliation. Furthermore, it's unclear whether the retaliating nation would tax the foreign subsidiary or branch of one of its own multinational enterprises in the face of inaction by other nations.

The second method of offsetting the benefit of a preferential tax regime takes advantage of the GATT regime of cross-retaliation to pressure interest groups within the offending nation to lobby for repeal of the preferential tax regime. Nations that import goods or services from the offending nation might impose countervailing duties on those imports, regardless of whether those imports were produced with the benefit of the preferential tax regime. The indiscriminate imposition of duties would help to ensure that interest groups within the offending nation lobbied for the removal of the preferential tax regime. We might need to modify the terms of GATT and GATS to define the benefit of any preferential tax regime as an export subsidy.

b. Countering Residence-Based Taxation of Business Income

The standards and limitations suggest that a nation should refrain from taxing the income of its residents' foreign branches and subsidiaries (other than under its anti-abuse regime). The taxation of foreign branches and subsidiaries is of concern only to host nations with lower tax rates than a multinational enterprise's home nation. Host nations with tax rates comparable to or higher than the home nation would see no effect from the residence-based tax system due to the workings of the home nation's foreign tax credit. ${ }^{167}$ Nations with lower tax rates include many with emerging markets.

To curb the taxation of foreign branches and subsidiaries, we must offer nations a treaty benefit that is contingent upon the

167. See GUSTAFSON, supra note 73, at 19-21 (comparing the exemption approach of territorial tax systems with the foreign tax credit approach of worldwide tax systems). 
adoption of an exemption system for the taxation of business income and that is withdrawn in the event that the nation reverts to the taxation of foreign branches and subsidiaries. Two treaty benefits relating to the taxation of portfolio income fill our need: the exchange of taxpayer information and the elimination of the substantial withholding tax on portfolio income discussed below. A treaty party that reintroduced the taxation of foreign branches and subsidiaries would see its residents' portfolio income burdened by a substantial withholding tax imposed by the advanced economies and would also see its own tax on portfolio income absorbed by its foreign tax credit and by tax evasion as it lost access to the information it needed to enforce its own tax on portfolio income.

The imposition of a substantial withholding tax would be ineffective unless all of the advanced economies were committed to do so on behalf of affected low-tax nations. Otherwise, interest groups within the offending nation would simply shift their portfolio investment to other nations. In addition, debtor nations, a category that includes many developing countries, would be reluctant to impose such a retaliatory withholding tax. Under typical international loan agreements, lenders charge any withholding taxes on their interest income to their borrowers. Thus, a retaliatory withholding tax would pit borrowers in the retaliating nation against the competitive position of the injured nation's tax on business income. For these reasons, the suspension of the exchange of taxpayer information by itself might be the likely form of retaliation.

An alternative secondary norm is the blocking statute, a form of retaliation that can be imposed unilaterally. ${ }^{168}$ A blocking statute forbids the repatriation of earnings by foreign subsidiaries or branches; the ban prevents the parent company from repatriating earnings with which to pay the tax levied by the home nation on the multinational group's foreign operations. A blocking statute has been sufficient to eliminate the U.S. tax liability of a U.S. parent company ${ }^{169}$ However, the frequent use of blocking statutes by host nations may lead home nations to ignore them and impose liability

168. Cross-retaliation by duties levied by the injured nation on goods and services imported from the offending nation would require the creation of a new norm of GATT. The new norm would have to outlaw the taxation of foreign branches and subsidiaries of resident enterprises.

169. See Proctor \& Gamble Co. v. Commissioner, 961 F.2d 1255 (6th Cir. 1992) (holding a Spanish blocking statute effective to prevent the imputation of income from a Spanish subsidiary to a Swiss-based foreign subsidiary of a U.S. corporation, and the U.S. taxation of that income). 
for tax regardless of the parent company's inability to repatriate the foreign income. Such a move would encounter internal resistance from the home nation's business groups. Blocking statutes also may run afoul of bilateral investment treaties, which frequently require the free repatriation of earnings by foreign investors.

\section{A Secondary Norm for the Taxation of Portfolio Income}

The primary norm for the taxation of portfolio income stipulates that a nation has exclusive prescriptive jurisdiction over the portfolio income of its residents. A nation may not tax the portfolio income of another nation's residents. When a nation departs from this primary norm and taxes the portfolio income of nonresidents, what is the appropriate secondary norm for other nations to follow? Other nations would be permitted to retaliate in two ways: first, by their conditional imposition of a substantial withholding tax on the portfolio income of the offending nation's own residents; and second, by the suspension of their treaty obligations to exchange information with the offending nation.

The retaliation would reduce the offending nation's tax collections from its own residents. If the offending nation offers a foreign tax credit to its own residents, the retaliation would transfer tax revenue from the offending nation to the retaliating nations. If the offending nation does not offer its residents a foreign tax credit and thus the retaliatory tax threatens to increase the tax burden on the offending nation's residents, the suspension of the exchange of information permits the offending nation's residents to evade their own nation's taxation of their portfolio income.

Nations could incorporate the secondary norm into their national tax codes as a default provision, that is, as a permanent provision that would be overridden by a nation's treaties as long as each treaty is honored. The withholding tax would apply to all payments of portfolio income made to addresses in non-treaty nations, including addresses in nations that did not engage in effective exchange of information. The withholding tax would also deter conduit arrangements through opaque tax havens and thus improve tax compliance in residence nations, if the rate at which the withholding tax is set exceeds the highest marginal rate on portfolio income set by capital exporting nations. ${ }^{170}$ In this way, the withholding tax serves as

170. We would also need to eliminate bearer bonds, which can be done by denying interest deductions to the would-be issuers. We might also enforce the primary norm by the denial of 
the secondary norm for another primary norm of international taxation: the primary norm requiring transparency in the administration of a nation's tax code so that other nations may verify the foreign portfolio income of their residents.

Would this secondary norm be effective? The widespread use of withholding taxes on nonresidents' portfolio income suggests that nations are not at all reluctant to impose such a withholding tax. After all, nonresident taxpayers don't vote. One possible exception is a withholding tax on interest payments to nonresidents. Resident debtors would argue against the reimposition of a withholding tax on interest payments, because under the typical international loan agreement any withholding tax on the lender's interest payments is charged to the borrower. The effectiveness of the secondary norm will turn on the willingness of offending governments to remove withholding taxes on portfolio income in exchange for an improved flow of information about (and improved flow of tax revenue from) their resident taxpayers. ${ }^{171}$ Financial institutions within the offending nation will be one source of pressure to drop the offending nation's withholding tax.

A multilateral treaty would be helpful for four reasons. First, a multilateral treaty is required to impose a withholding tax on interest income. ${ }^{172}$ Such a tax could not be imposed unilaterally, given the current lack of withholding on portfolio interest income. No nation would be willing to see inflows of portfolio investment diverted to other nations. Second, a multilateral treaty would assist in the creation of a regime for the exchange of tax information among nations. Under the terms of a multilateral treaty, information received by one nation from another could in turn be passed on to a third nation. Third, a multilateral treaty would be required to create a

deductions for payments made to addresses in nations that violate the primary norm and by the prohibition of bank transfers to those addresses. Unfortunately, both measures require global and perfect information exchange. Either measure could be evaded by making the payments to a recipient in a third nation, who would forward the payments on to a recipient in the offending nation. In the case of a withholding tax, we must depend on the limitation-of-benefits provision in the tax treaty with the third nation bolstered by information exchange with that third nation to identify conduit payments into the offending nation against which the withholding tax is aimed.

171. One insightful analysis has raised the possibility that national decision-makers actually condone the evasion of domestic taxes by wealthy taxpayers through the use of tax haven intermediaries. See Roin, supra note 48, at 599-601.

172. See Avi-Yonah, Globalization, supra note 52, at 1667-70. For this purpose, the membership of a multilateral treaty could begin with OECD members, the primary destination for foreign portfolio investment. 
refundable withholding tax. A refundable withholding tax can reinforce a regime for the exchange of information. An investor resident in a treaty nation would be able to obtain a refund of the withholding tax by reporting its portfolio income to its nation of residence. ${ }^{173}$ An investor resident in a tax haven would receive no refund, if the tax haven were not a party to the multilateral treaty. Multilateral action would be required to create the necessary clearinghouse among nations for refunds to investors and net tax collections to nations. Tax-exempt organizations and tax-exempt collective investment vehicles such as pension funds could receive a full refund of the tax. Fourth, a multilateral treaty would ease the transition away from the reciprocity found in bilateral treaties in reductions in withholding taxes. ${ }^{174}$

\section{A Multilateral Treaty and Collective Action Problems}

A multinational treaty would be useful in the creation of effective secondary norms of measured retaliation to enforce the primary norms of international taxation. Such a treaty would set out the primary norms so that the proper application of the secondary norms is known. ${ }^{175}$ Furthermore, the treaty could establish a mechanism for the resolution of disputes about whether violations of the primary norms have occurred and about the proper use of the secondary norms. ${ }^{176}$ This structure of primary norms, secondary norms of measured retaliation, and a dispute resolution mechanism is already present in GATT, which suggests that we might take the

173. See id. at 1668-69 (proposing a refundable withholding tax).

174. Alvin Warren has argued for the abandonment of reciprocity in favor of reformed notions of nondiscrimination and neutrality that take into account the integration of corporate and personal income taxes. See Alvin C. Warren, Jr., Alternatives for International Corporate Tax Reform, 49 TAX L. REV. 599, 611-13 (1994); see also Julie Roin, Rethinking Tax Treaties in a Strategic World With Disparate Tax Systems, 81 VA. L. REV. 1753, 1755-56, 1799 (1995) (advocating the adoption of treaties allowing a greater measure of source taxation when nations' tax systems differ with regard to the integration of corporate and personal income taxation).

175. In game theoretic terms, treaties provide the communication between parties that is required in strategic situations calling for multilateral cooperation and coordination. See Goldsmith \& Posner, supra note 161, at 1131, 1170-72.

176. Others have pointed out that a multilateral treaty is needed to address preferential tax regimes, apportionment formulae for the income of multinational enterprises, electronic commerce, treaty overlaps, treaty shopping, and triangular tax treaty problems. See Victor Thuronyi, International Tax Cooperation and a Multilateral Treaty, 26 BROOK. J. INT'L L. 1641, 1644, 1651, 1654-55, 1661-62 (2001); Diane M. Ring, Prospects for a Multilateral Tax Treaty, 26 BROOK. J. INT’L L. 1699, 1701 n.3 (2001). 
approach of incorporating within GATT the terms of a multinational tax treaty. ${ }^{177}$

A multilateral treaty would also be useful in the creation of a multilateral withholding tax on portfolio income, a refund mechanism for the withholding tax, and multilateral information exchange. The tax treaty could take the form of a pluralateral treaty chiefly among OECD members, who together are the primary location for portfolio investment.

A drawback of a multilateral treaty, however, is the opportunity its negotiation presents for collusion among sovereigns to engage in anti-competitive behavior, such as an agreement to harmonize tax rates.

\section{CONCLUSION}

This Article proposes the institutional competence of nations in global economic development as a foundation for international tax law. A notion of constrained sovereign discretion lies at the heart of the proposal.

The Article constructs the institutional competence of nations in global economic development from institutional economics, simple game theory, and the literature on social norms. The Article expresses the institutional competence of nations through standards and limitations that reduce the abuse of sovereign discretion and address international collective action problems in the pursuit of global economic development. These standards and limitations allocate prescriptive jurisdiction among nations over the global income tax base.

The Article began its project by reviewing the value to global economic development of the use of multiple, autonomous decisionmakers to shape the world's economic environment. The use of multiple, sovereign decision-makers gives us, among other benefits, sovereign competition and a variety of approaches in the design of

177. Reuven Avi-Yonah suggests the WTO as the appropriate organization to address preferential tax regimes. He points out that the organization already addresses tax matters that affect international trade and has bolstered its expertise in tax matters. Avi-Yonah, Treating, supra note 91 , at 1689-92 (referring to preferential tax regimes as "harmful tax competition"). Victor Thuronyi would institute an evolutionary process that ultimately would yield a multilateral treaty separate from GATT, administered by an independent international organization. Thuronyi, supra note 176, at 1667-80. Diane Ring would begin with focused, topical multilateral agreements and offers suggestions on voting structure and power within an eventual international tax organization. Ring, supra note 176, at 1703-07. 
national economic environments. A variety of approaches is essential because it enables us to use the comparative method to evaluate the relative efficacy of different economic environments, thus partly overcoming our inherent lack of information about endowments, our inability to use controlled experiments in the public sphere, and the inevitable incompleteness of decision-making. Hence, the institutional competence of nations ratifies the existence of sovereign discretion in global economic development.

Nations can abuse their sovereign discretion, however. The immediate needs of a nation's public decision-makers and the efforts of organized groups to ameliorate market conditions can be causes of such abuse. The design of institutions within a nation's economic environment reflects the goals and transaction costs of legislators, interested constituents, and the holders of residual interests.

The abuse of sovereign discretion may take several forms. A nation might depart from the goal that justifies the existence of its discretion in economic development, possibly exploiting individuals for the benefit of various organized groups. A nation might also export costs to, or import benefits from, other nations.

To limit such abuse, the Article turned to standards and limitations to define the institutional competence of nations. Among other constraints, the Article discussed standards of neutrality for legislation and limitations on subsidies, in both cases drawing on our experience with the General Agreement on Tariffs and Trade.

The Article also proposed three norms of international law that would limit a nation's discretion to design its tax code. First, a nation would have exclusive prescriptive jurisdiction over the income derived from business operations conducted within its territory. Second, a nation would have exclusive prescriptive jurisdiction over portfolio income derived anywhere in the world from capital accumulated within its territory. Third, a nation's tax code must be transparent to the tax authorities of other nations when the nation acts as a conduit for portfolio investment. These primary norms of international tax law would be subject to permissible anti-abuse regimes and the secondary norms mentioned below.

The three primary norms are based on the value to global economic development of capital formation, a variety of approaches to the design of national economic environments, including the size of a nation's public sector, and of sovereign competition. It is only through the comparison of different economic environments that we may determine the effect of different institutional arrangements on 
economic performance. Global economic development must take into account adaptive efficiency as well as allocative efficiency. As a species of allocative efficiency, the traditional tax policy of capital export neutrality is subordinate to the economic design of institutions that promote the well-being of the world's people.

Furthermore, to gain the full benefit of decentralized decisionmaking among the world's nations, we must preserve incentives for national decision-makers to be attentive to the design of a nation's economic environment and to capital formation within that environment. Chief among those incentives is the tax revenue generated by an economic environment and by capital formation.

These limitations suggest that a national tax code consist of an exemption system for the business income of residents, source-based taxation of nonresidents of their business income from permanent establishments, a worldwide system for portfolio income derived from capital accumulated within the nation's economic environment, a conditional absence of taxation of nonresidents' portfolio income derived from capital accumulated elsewhere, an anti-abuse regime similar to today's anti-deferral regimes, and a conditional exchange of tax information with other nations. Neither a foreign tax credit nor a preferential tax regime should be included in a national income tax code. A nation would be free to set its tax rate at whatever level it determines best for economic development, subject to the constraints of international capital markets and sovereign competition.

The Article then addressed collective action problems among sovereign decision-makers. Anti-abuse regimes are one method of coordinating collective action. Those regimes deter tax evasion by enterprises attempting to make only phantom choices among national economic environments for their business operations or place of residence. Treaties are a second method of coordinating collective action. Tax treaties facilitate the movement of nations toward the primary norms of international taxation.

The primary norms of international taxation are the international equivalent of social norms. To the extent these norms are not selfenforcing, we must devise secondary social norms for their enforcement. Those secondary norms would be embodied in national tax codes, bilateral tax treaties, or a multinational tax treaty.

The Article proposes three secondary norms of international taxation. First, a nation may tax currently a resident's business income derived under another nation's preferential tax regime or, as an alternative, may impose measured import duties on products and 
services produced under a preferential tax regime. Second, a nation may impose a conditional and substantial withholding tax on portfolio income paid to residents of a particular nation. Third, a nation may suspend its exchange of tax information with a particular nation. A nation would be able to pursue the second and third norms either in response to another nation's residence-based taxation of business income or in response to another nation's taxation of nonresidents' portfolio income.

A multilateral tax treaty is required to define the primary and secondary norms, to resolve disputes about possible violations of the norms, and to authorize the imposition of secondary norms as measured retaliation for violations of primary norms. Such a treaty would bear similarities to the General Agreement on Tariffs and Trade and could be incorporated into the body of agreements administered by the World Trade Organization. 